\title{
QE
}

184

A1A512

[1921

WMAH

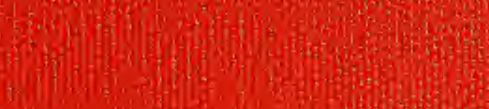



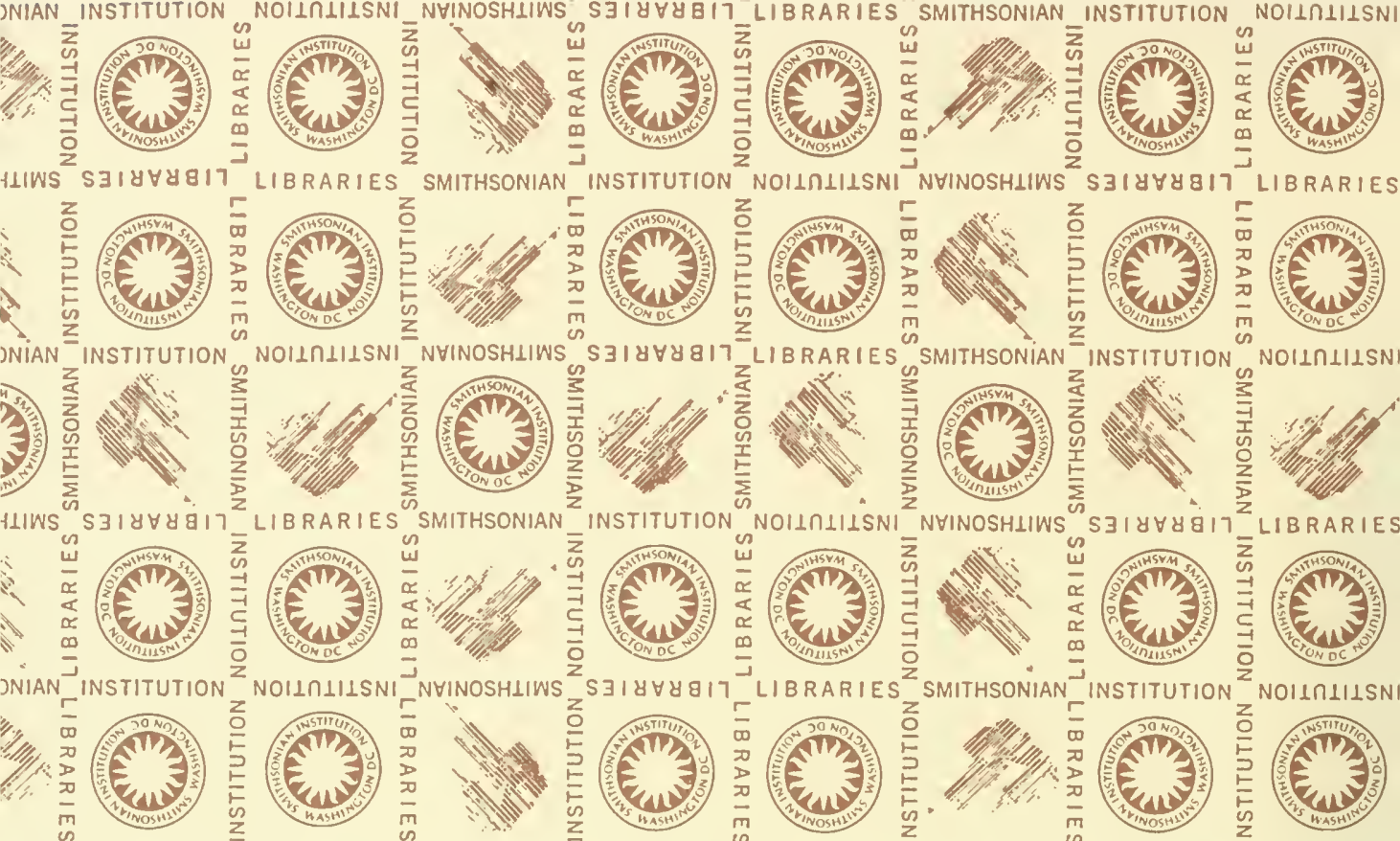

NOILILILSN
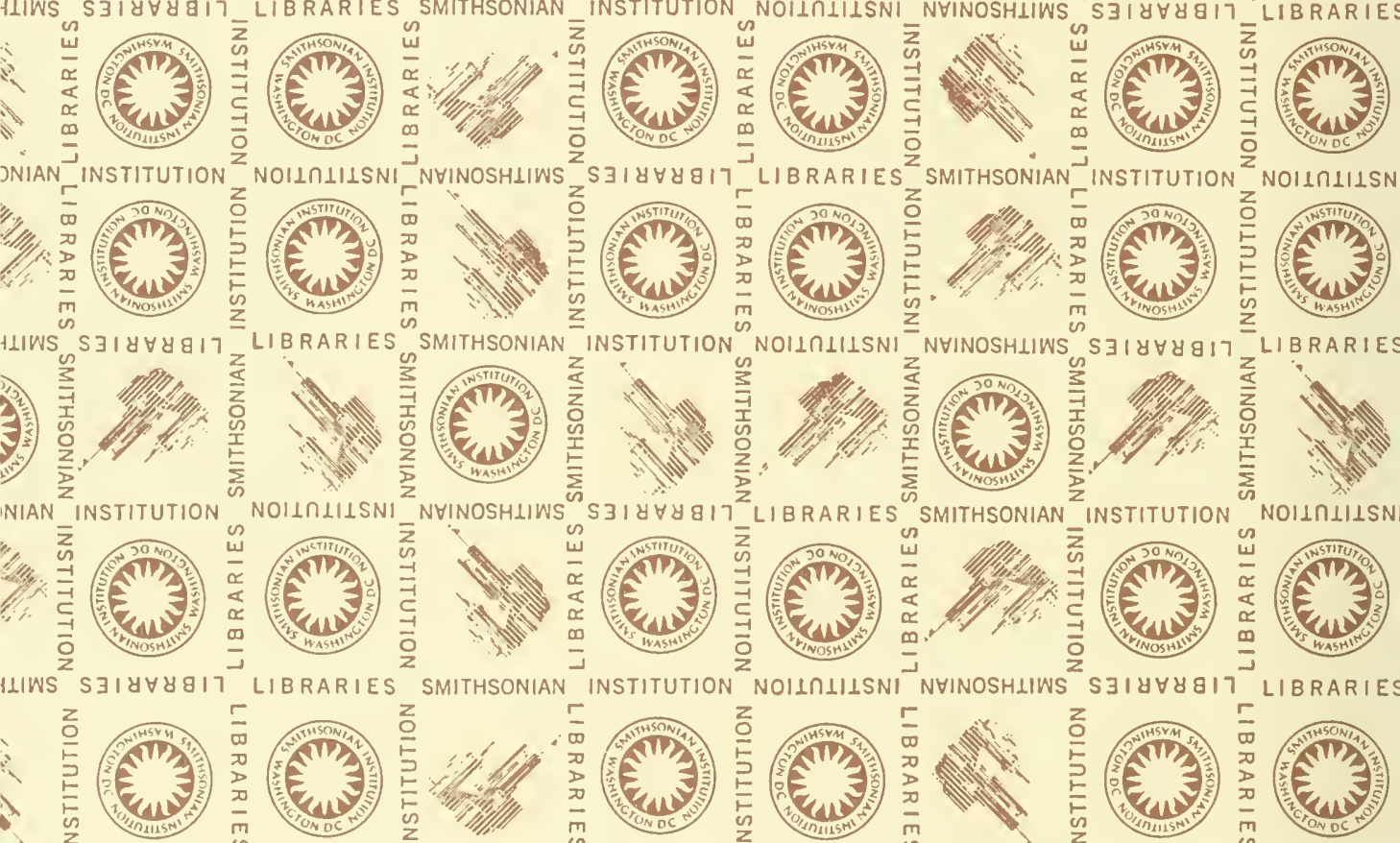

NOIINIILSN

NOIINLILSNI NVINOSHLIWS
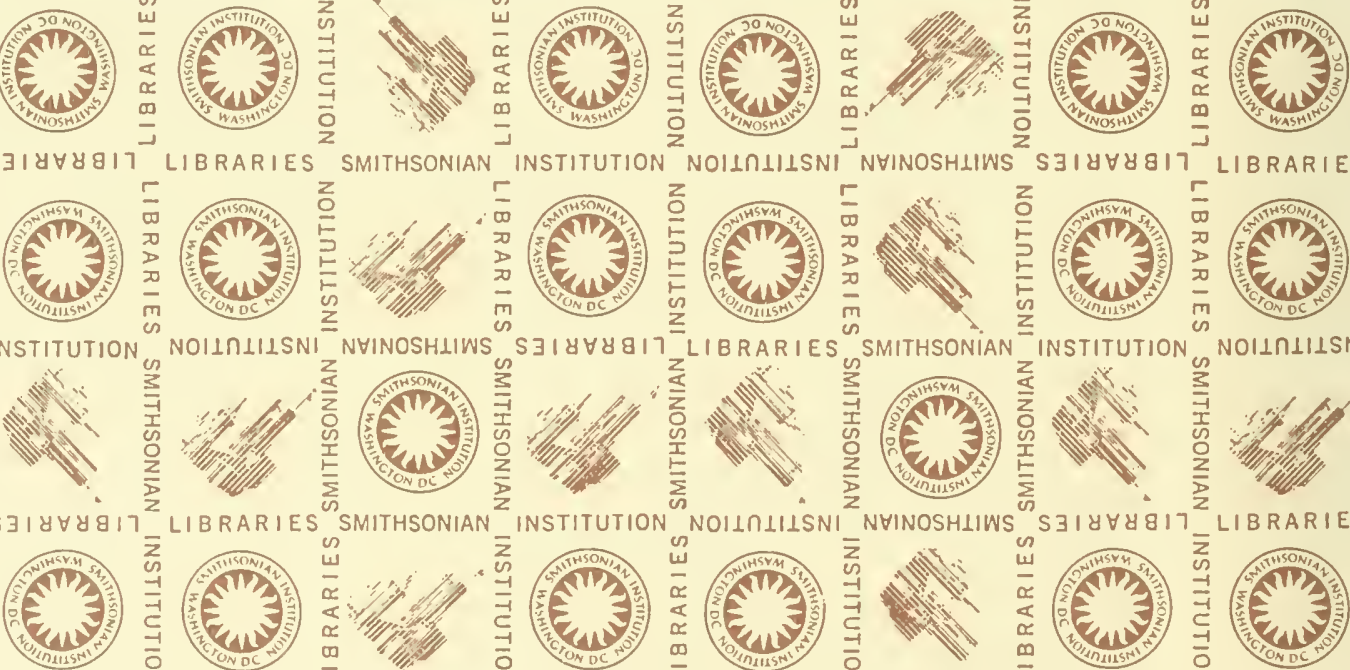

3.
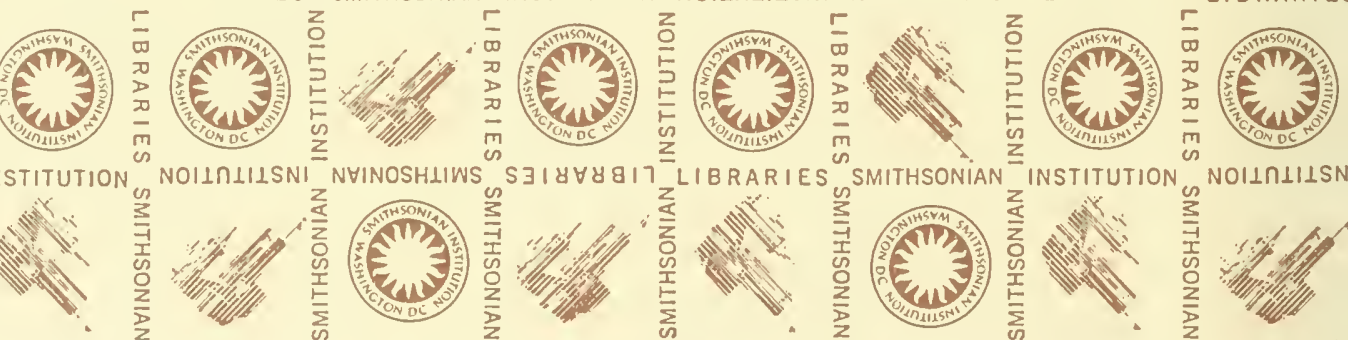

NOILNIILSN
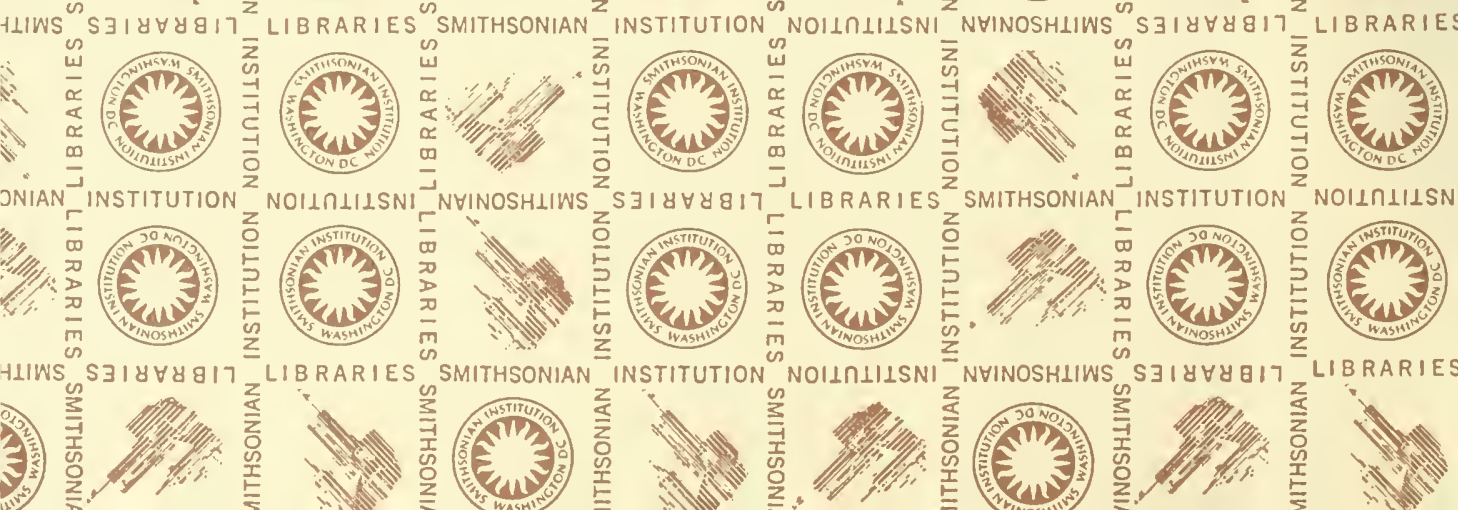

S S SIYYYE17 LIBRARIES 
(3)

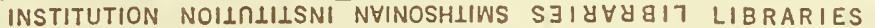
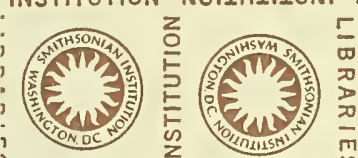

S 31 Y $\forall$ प917 LIBRARIES
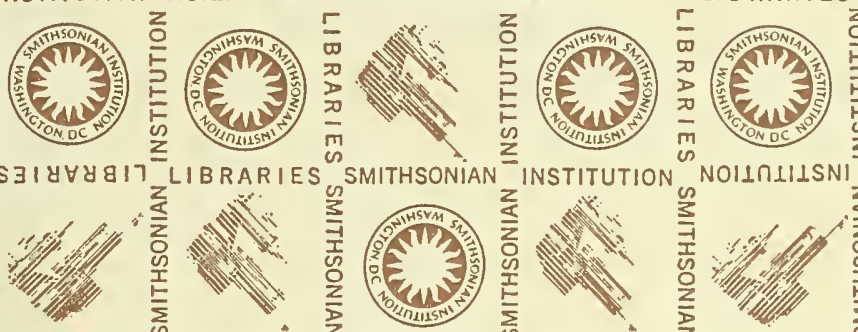

$\frac{z}{5}$
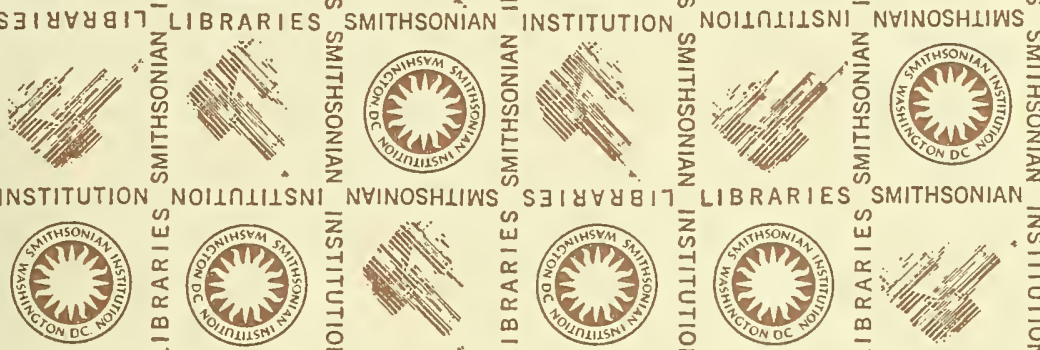

$S \exists I Y \forall Y 817^{2} L I B R A R I E S$ INSTITUTION "NOILIIISNI
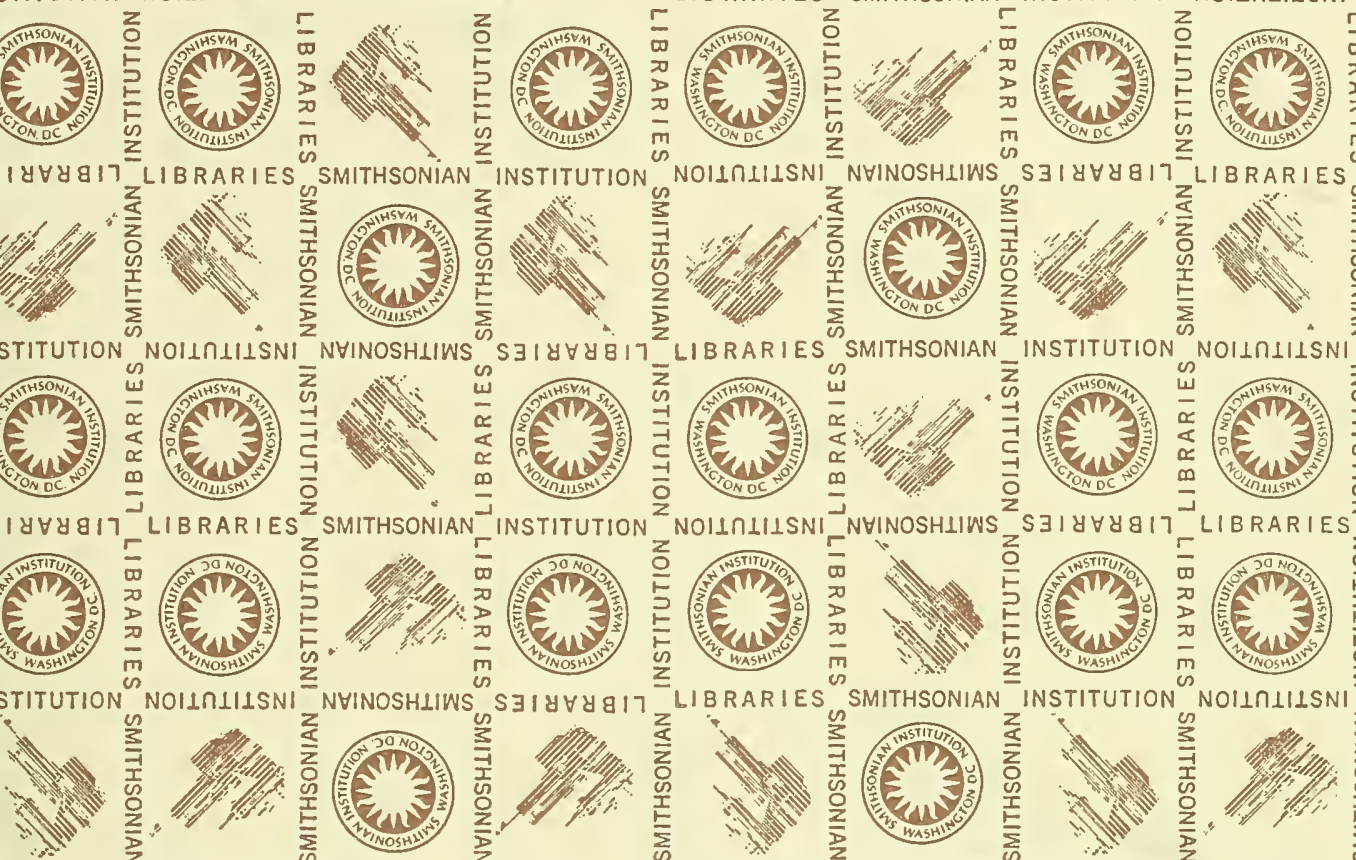

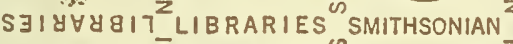
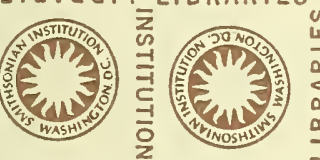

INSTITUTION NOIINIILSNI

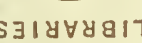

$S \exists$
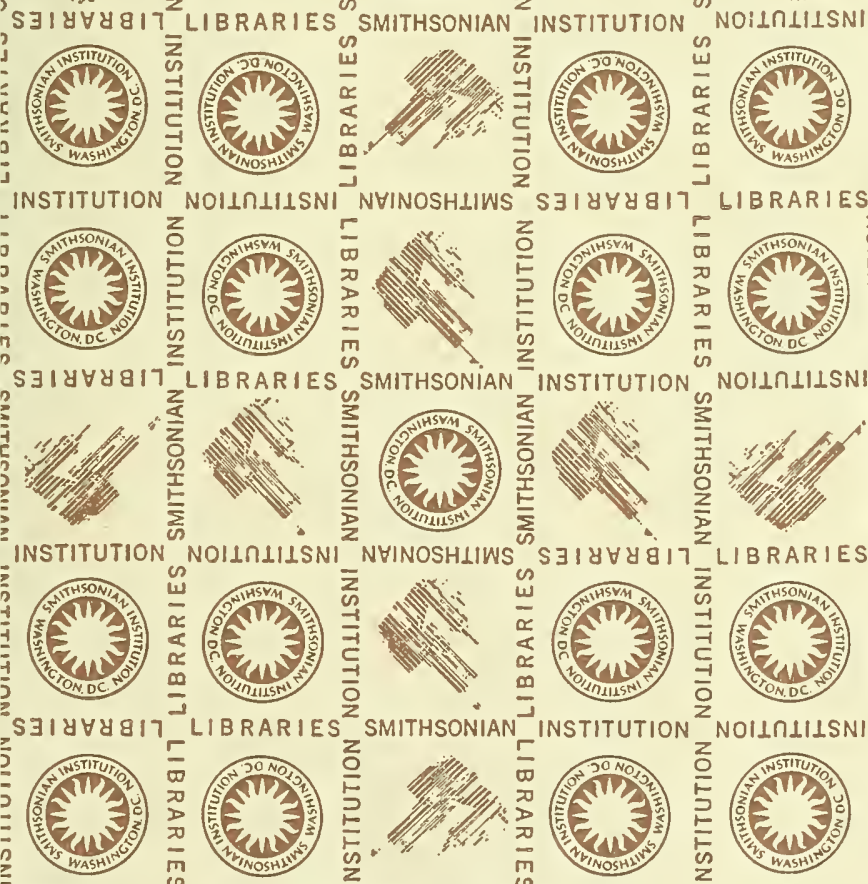

LIBRARIES
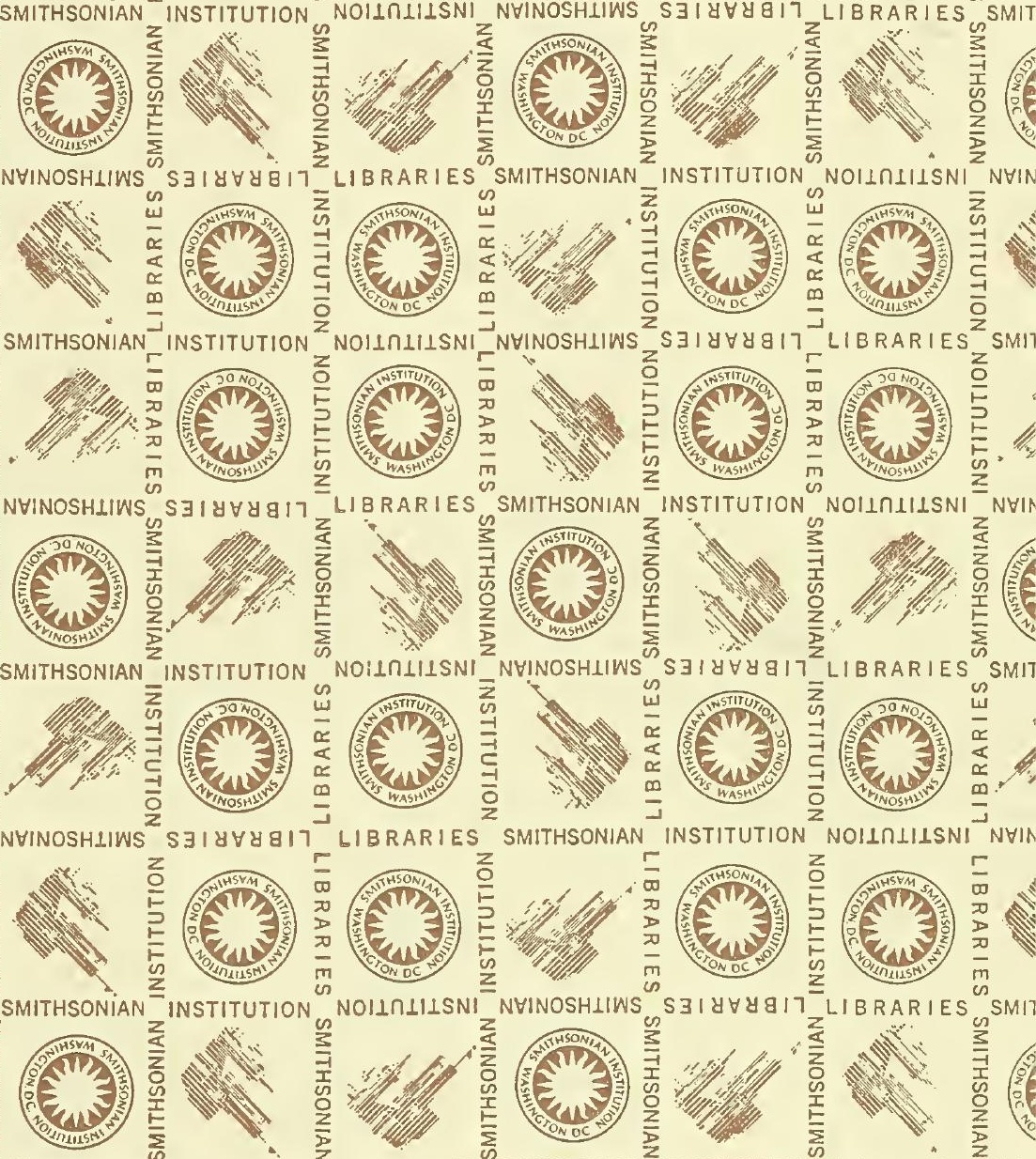

京

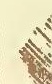

1ै 

Wot to te laken fro
Office

The Book of

AMERICA'S MAKING

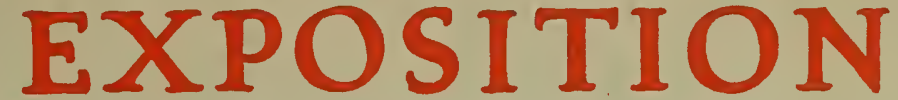

71ST. REGIMENT ARMORY

NEW YORK

OCTOBER $29 \sim$ NOVEMBER 12

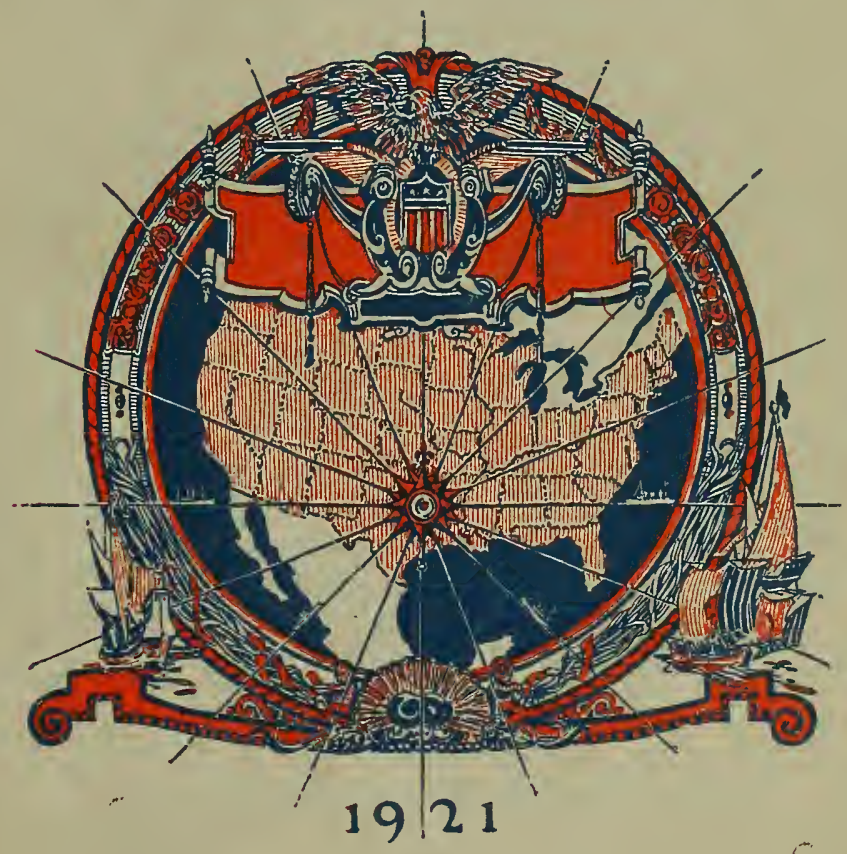

UNDER the AUSPICES of CITY and STATE DEPARTMENTS of EDUCATION 



$$
\begin{aligned}
& 9 \text { F } 84 \\
& \text { A A } 512 \\
& \text { I } 21
\end{aligned}
$$

\section{The BOOK of}

\section{AMERICA'S MAKING EXPOSITION}

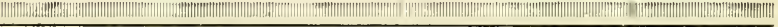

Citizens by birth or choice of a common country, that country has a right to concentrate your affections. The name AMERICA which belongs to you, in your national capacity, must always exalt the just pride of Patriotism.

With slight shades of difference, you have the same Religion, Manners, Habits and Political Principles. You have in a common cause fought and triumphed together. The Independence and Liberty you possess are the work of joint councils and joint efforts - of common dangers, sufferings and successes.

- Washington's Farewell Address.

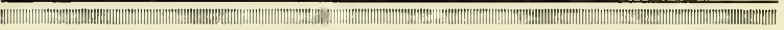

HELD AT THE 71sT REGIMENT ARMORY, NEW YORK

OCTOBER $29 \mathrm{TH}-\mathrm{NOVEMBER} 12 \mathrm{TH}, 1921$

This book has been arranged in cooperation with the various groups which participate in the Exposition and the pages have been prepared from material submitted by them.

Under the Auspices of

CITY AND STATE DEPARTMENTS OF EDUCATION, NEW YORK 


\section{FORE WORD}

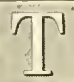

HERE can be no better preface to this catalogue than these words written by Franklin $\mathrm{K}$. Lane shortly before his death. I remember his writing this message, but it has only to-day heen recovered. It has doubtless been published, and if the place of its publication were known credit would be given. But it manifestly helongs to America's Making, whose purposes it so fitly and feelingly expresses:

America is a land of but one people, gathered from many countries. Some came for love of money and some for love of freedom. Whatever the lure that brought us, each has his gift. Irish lad and Scot, Englishman and Dutch, Italian, Greek and French, Spaniard, Slav, Teuton, Norse, Negro-all have come bearing gifts and have laid them on the Altar of America.

All brought their music-dirge and dance and wassail song, proud march and religious chant. All brought music and their instruments for the making of music, those many dhildren of the harp and lute.

All brought their poetry, winged tales of man's many passions, folk songs and psalm, ballads of heroes and tunes of the sea, lilting scraps caught from sky and field, or mighty dramas that tell of primal struggles of the profoundest meaning. All brought poetry.

All brought art, fancies of the mind, woven in wood or wool, silk, stone or metal-rugs and haskets, gates of fine design and modeled gardens, houses and walls, pillars, roofs, windows, statues and painting-all brought their art and hand craft.

Then, too, each brought some homely thing, some touch of the familiar home field or forest, kitchen or dress-a favorite tree or fruit, an accustomed flower, a style in cookery or in costume-each brought some homelike, familiar thing.

And all brought hands with which to work.

And all brought minds that could conceive.

And all brought hearts filled with home--stout hearts to drive live minds; live minds to direct willing hands.

These were the gifts they brought.

Hatred of old-time neighbors, national prejudices and amhitions, traditional fears, set standards of living, graceless intolerance, class rights and the demand of class-these were barred at the gates.

At the Altar of America we have sworn ourselves to a single loyalty. WTe have bound ourselves to sacrifice and struggle, to plan and to work for this land. We have given that we may gain, we have surrendered that we may have victory. We have taken an oath that the world shall have a chance to know low much of good may be gathered from all countries and how solid in its strength, how wise, how fertile in its yield, how lasting and sure is the life of a people who are one.

It is with this purpose, so loftily defined, that we present this catalogue intimating the contribution which each group has brought to the making of our beloved America.

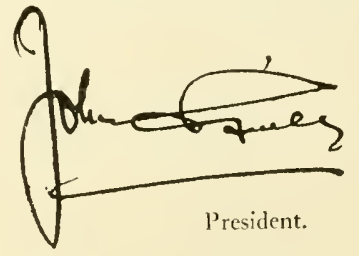




\section{OUR ORGANIZATION}

I)

N times past much has been said of what America has done for the immigrant. In America's Making we tell what the immigrant has done for America. 'The focus of attention is shifted. The immigrants themselves are asked to look at the present and the future- not the past; to feel and to show themselves part of this new nation which we all-Americans of many origins-in common purpose, each in our distinctive capacity, are helping to build.

The plan of America's Making was organized by a central body of people with the help of thirty-two volunteer groups.

Its purpose is to show in popular form by means of exhibits and pageantry the most important historical, economic and cultural contributions that Americans of various descent, from the original colonists down to the present, have made to the American nation-thus to deepen our common understanding of the ideals of our country.

Committees of Americans whose ancestors came from countries over thirty in number, organized to participate in the drama of a nation's life. Each group conceived, arranged and financed its own exhibit. No measure can be taken of the devotion of these busy men and women who have given time and thought unstintingly and voluntarily over a long period of months to prepare their contribution of art, their Festival of dance and song and tableau, that all the land might know what was their part in the great American story.

The State and City Departments of Education and the Parochial Schools gave hearty support. Extensive research was conducted. More than one thousand programs of music, processional and pageantry were presented during October by teachers and pupils in school auditoriums, parks and playgrounds to denonstrate the part played by various nationalities in the building of the United States. With untiring devotion hundreds of teachers have given their energy and imagination for long hours of service, rewarded only by the joy of helping in a glorious cause.

The executive work developing upon the central body was supported by the counsel of many good and disinterested citizens. In the center of this book are the names of the workers in every group who were the heart of this mighty project.

\section{OFFICERS}

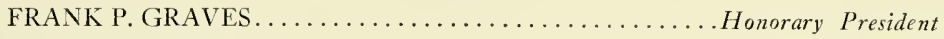

JOHN H. FINLEY ........................... President

WILLIAM L. E'TTINGER....................... Vice-President

MRS. H. EDIVARD DREIER..................... Secretary

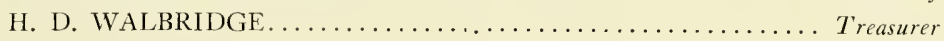

\section{EXECUTIVE COMMITTEE}

WILLIAM C. SMITH, Chairman

SEYMOUR BARNARD

ALLEN T. BURNS
ALLEN EATON

WILLIAM MCANDREW

M. E. RAVAGE

EDIVARD F. SANDERSON 


\title{
OUR ORGANIZATION-Continued
}

\author{
GENERAL STAFF
}

MATILDA SPENCE, Acting General Director CIARLES J. STOREY, Director of Exhibits ELIZABETII BURCHENAL, Director of Festival Programs RUTII BLRCHENAL, Consultant on Forms and Ceremonies A. R. ROGERS, Business Manager FLORENCE $K$. TAG, Office Manager HOW.ARI) GREENLEY, Director of Decorations IIARWOOD, INCORPORATED, Puhlicity American Press ERNEST L. MANDEL, Director of Publicity Foreign Language Press

MRS. SESMOLR BARNARD, Director of Historical Research S. G. LINHOLM, Director of Economic Research MISS ELIZABETII ROEMER, Research and Organization IVILLIAM I1. HUMISTON, Director of Music RICIIARD (LARK, Stage Manager JEANNETIL EATON, Catalog and Program Elitor

\section{GENERAL COMMITTEE}

John G. Agar E. H. Anderson Frank J. Arnold Chas. D. Atkins John C. Atwater Robert E. Auld Francis I), Blodgett Wrilliam Bondy Arthur A. Boylan Mary L. Brady Herbert L. Bridgman Robert B. Brodie Elmer Ellsworth Brown James Byrne Harry B. Chambers Thomas WV. Churchill Philander P. Claxton

Mary A. Conlon

Royal S. Copeland Ambrose Cort Wrm. Nelson Cromwell George S. Davis Katharine B. Davis Robert W. De Forest Cleveland H. Dodge Thomas J. Donohue Thomas M. Donohue Timothy F. Donovan George W. Dorland Miss Miriam S. Draper John J. Driscoll

E. F, Eilert

Abram I. Elkus

Frederic Ernst
$11 \mathrm{~m}$. L. Ettinger

Livingston Farrand

Daniel D. Feldman

Wrillian I. Felter

John A. Ferguson

Alexander Fichandler

John S. Fitzpatrick

Raymond B. Fosdick

IV. H. Fox

II ugh Fravne

Michael Friedsam

George H. Gartlan

Edwin F. Gay

Frank B. Gilbert

William E. Grady

Frederick B. Graham

Susan A. Grition

Herbert F. Gunnison

Herman Hagedorn

James A. Hamilton

Joseph A. Haniphy

John N. Harman

Henry E. Hein

Frank P. Hill

Simon Ilirsdansky

John F. Hylan

Henry E. Jeukins

Patrick Jones

Otto II. Kahn

Franklin J. Keller

Mary B. Kinkeldey

Margaret Knox

Leo Levitsky

Alolph Lewisohn

John Lieberman
John J. Loftus
Ahraham London
Michael H. Lucey
James J. McCabe
William P. McCarthy
Margaret J. McCooey
William J. McGrath
V. Everitt Macy
Louis A. Maiks
Alfred E. Marling
Gabriel R. Mason
Sidney Edward Mezes
E. M. Morgan
Frank A. Munsey
Emma L. Mulray
John T. Nicholson
Lucille Nicol
Eugene A. Noble
Morgan J. O'brien
Adolph S. Ochs
James A. O'Donnell
E. E. Olcott
James J. O'Regan
IIenry Fairfield Osborn
Angelo Patri
Anna 1. Phillips
Chas. J. Pickett
Anning S. Prall
Frederic B. Pratt
Anthony J. Pugliese
Ralph Pulizer
William Rabenort
William M. Rainey
Mond

Ogden Reid

Frederic J. Reilly

Josephine Roche

Jason Rogers

Geo. J. Ryan

Mrs. Henrietta B. Scheider Oswald Schlockow

Albert Shiels

William M. Simmons

Alfred E. Smith

Samuel McK. Smith

Arthur S. Somers

Isidore Springer

Charles E. Springmeyer

M. Samuel Stern

E. F. Stevens

Edward IV. Stitt

Henry L. Stoddard

Mrs. Willard D. Straight

Charles F. Thellusson

Jacob Theobald, Jr.

Mrs. Charles L. Tiffany

John J. Tigent

E. R. Tivnan

Kate E. Turner

Rufus A. Vance

Joseph K. Vandenburg

Mrs. Frank A. Vanderlip

Samuel Viertel

William J. Wallin

Mabel Williams

Talcott Williams

Frank D. Wilsey

The general plan of the decorative ensemble for the Exposition, including stage settings and lighting effects, was designed and installed by Castlebridge, Inc. 


\section{WHERE AMERICA-MAKING IS A REGULAR BUSINESS}
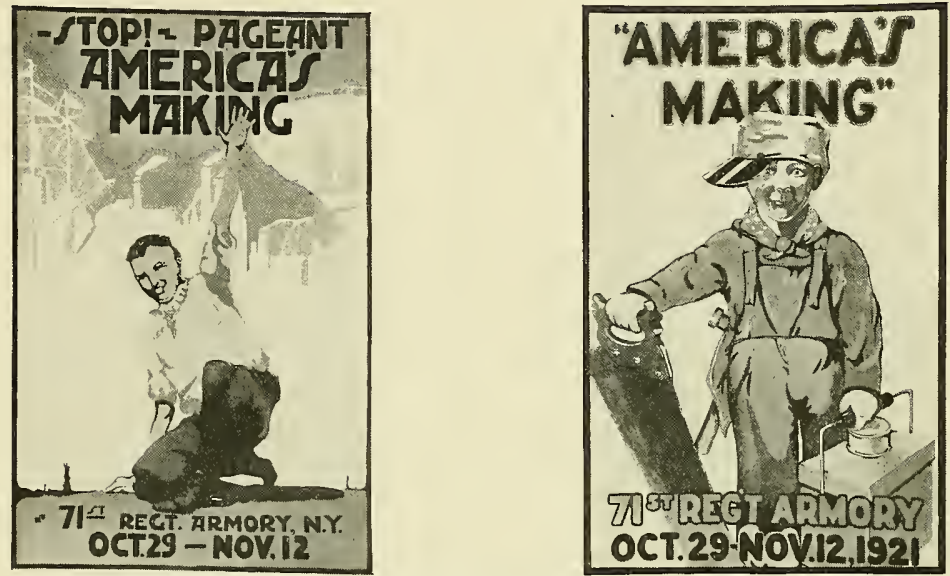

Forty-Eight Thousand Three Hundred Seventy-Six Posters for America's Making, Each an Original Design, Have Been Made by Children of the Public Schools

$\mathrm{F}$ and when American school boys shall have been taught by their parents to be kind to the lonesome kid with a foreign accent in his voice and not to join coward-like with a mob of young savages to beat him up; if and when American school girls shall be trained at home that, in place of feminine cruelty, it is more American to exercise generous sisterhood; schools will then be able to regard the purpose of the festival, America's Making, as a thing accomplished and an unnecessary interference with the good old school essentials of readin' riten' and 'rithmetic. But every teacher knows that, absorbed from somewhere out of an unkindly past young human nature brings to school the unhappy traditions of race prejudice, social snobbery, and pride of birth, fostered by some lines of immigrants who landed earlier than some other groups.

It is fitting, therefore, that the managers of public schools have welcomed the occasion of this festival. In 590 centres, day schools, evening schools, a total of 1706 programs of pageantry, processions, tableaux and dramatic representations was devoted during the month of October to the revival of American fraternity, equality, fair mindedness and good will. Upwards of two million Americans were shown the respectable additions to our civilization made by the immigrants of every blood who have entered into the life of the nation since 1492. Spread-eagleism, boasting, national conceit, for a month at least have been reprobated by the schools. They have featured education's persistent purpose of perpetuating justice, modesty, honesty and a patriotism based on truthth and fair play. In the final celebrations at the armory 45 schools join with adult citizens in teaching the great lesson.

Sixty-eight thousand adults are getting the message of America's Making through the public nifht schools while the entire series of public lectures for six weeks has been upon this theme. 


\section{AMERICANS OF ARMENIAN LINEAGE}

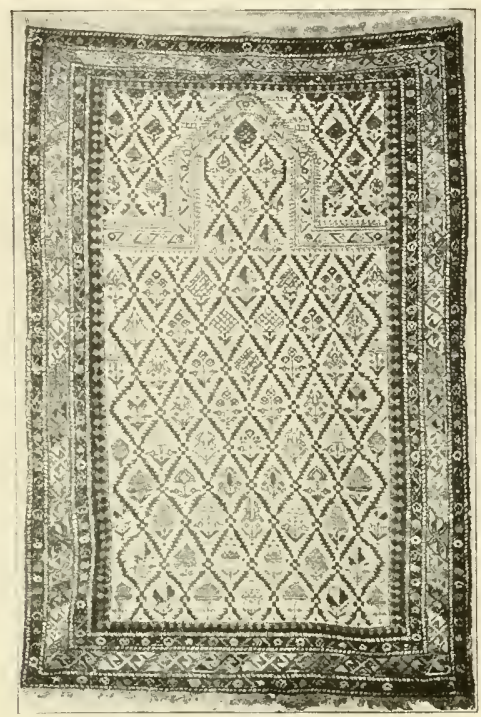

ONE OF THE BEAUTIFUL RUGS BROUGHT FOR AMERICAN IIOMES ALL OIER THE COUNTRY BY MERCHANTS OF ARMENIAN LINEAGE

HE immigration of Armenians to the United States is of comparatively recent date. Excepting the early settlers, about 4,000 in number, the majority of Armenians have come to America since 1894. According to reliable sources of information, there are at present approximately one hundred thousand people of Armenian lineage, most of them in the Eastern States. Important colonies have also settled in the Middle West and on the Pacific Coast.

One of the earliest Armenian activities in America has been the cultivation of the silk worm, a contribution which received official recognition from the Assembly of Virginia in 1656. Two technical processes which have proved of concrete value to American institutions are the formula for green ink used in the printing of paper money and a preservative for stone. The conservation of Plymouth Rock is due to the ingenuity of Americans of Armenian descent.

Armenian capital has established a large business in the importation and sale of rugs and in the manufacture of domestic rugs. In the art of photo-engraving, in the manufacture of machinery, jewelry, embroideries and silk, Armenian-born Americans are preeminent.

Proportionately, the Armenians in the United States have produced a large number of professional men. There are over twenty professors of Armenian lineage in leading universities and colleges in this country. Scientists, physicians and dentists have attained marked distinction in their profession.

The exhibit of this group shows the special technical processes which have been such a unique gift to America; the green ink featured on a dollar bill; stone preservation demonstrated by a model of Plymouth Rock; and fermented milk. The exhibit suggests the color and mystery of the Orient which these Americans brought with them. 


\section{AMERICANS OF BELGIAN LINEAGE}

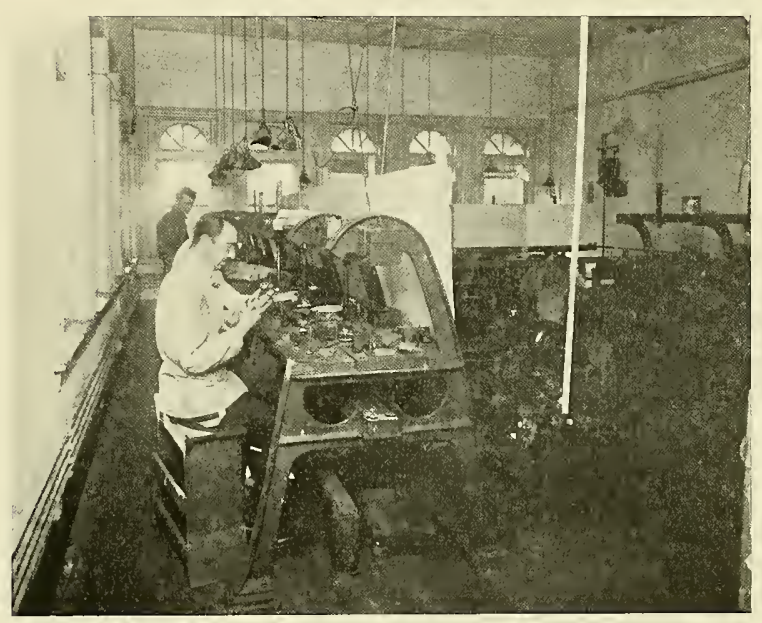

An American of Belgian lineage at his trade of diamond cutting

ECAUSE of the small size and pre-war prosperity of Belgium, immigration from this country to America has been comparatively light. Indeed, its occurrence is known to few. Nevertheless, the number of Belgian immigrants is proportionately high. Moreover, they have entered into many American activities and have a share in her history. Louis Hennepin, the Belgian Franciscan, was among the famous explorers of the American Continent. Father de Smet, the missionary, was noted for his wonderful success in spreading among the Indians the gospel of Peace on Earth.

Sturdy and healthful, the Belgian immigrant is a valuable addition to the great American family. With his love of work, his habits of thrift and saving, he has always held a firm place in American industry and agriculture. He sets an example of the way to become prosperous on small earnings which is as astonishing to the average American as it is beneficial.

The making of glassware and lace shown at the exhibit is typical of the occupations in which Belgian descendants are engaged in America. Diamond cutting, another trade in which they are highly skilled, is demonstrated. The early Jesuit explorers from Belgium are typified by a statue of Father Smith. In the exhibit among the human accomplishments stands the figure of a valued immigrant from Belgium-the Belgian draft horse. 


\title{
AMERICANS OF CARPATHO-RUSSIAN LINEAGE
}

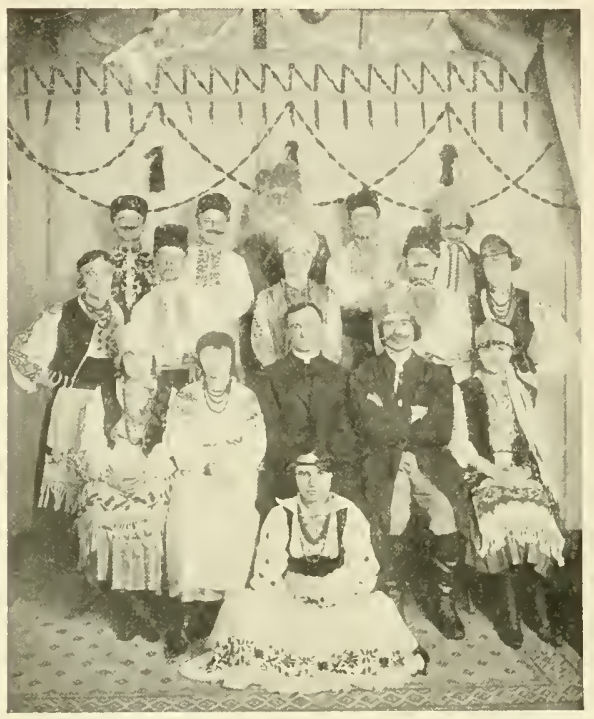

\author{
CHOIR \\ IN NATIONAL \\ COSTUME
}

BOUT fifty years ago began the Carpatho-Russian immigration to the United States. In this period there have settled here about one million people born in East Galicia, Lemkovschina, Bukovina and Karppatskaya Russ.

Although they are to be found in many branches of industry, steel mills, iron works, sugar, rubber and textile manufactories, yet half of them are concentrated in hard and soft coal mines. Their hands feed the great plants and factories which produce the vast wealth of America. In Pennsylvania whole colonies are settled exclusively by citizens of Carpatho-Russian lineage.

Among the younger generation are found successful business men, inventors, lawyers, physicians, federal and state employees. They are well organized, boast more than ten periodicals, and have established special libraries and schools. Their choirs and bands have enriched the musical expression of the community and their clubs its social life.

Their support of America during the World War was earnest. They bring to the country of their adoption a warm appreciation of the liberty it affords and a vivacious eagerness to make use of its opportunities.

The exhibit of Americans of Carpatho-Russian lineage covers their work in coal mines and steel and iron plants. Beautiful embroideries are displayed and a group of dolls show the national costume. 


\section{AMERICANS OF CZECHOSLOVAK LINEAGE}

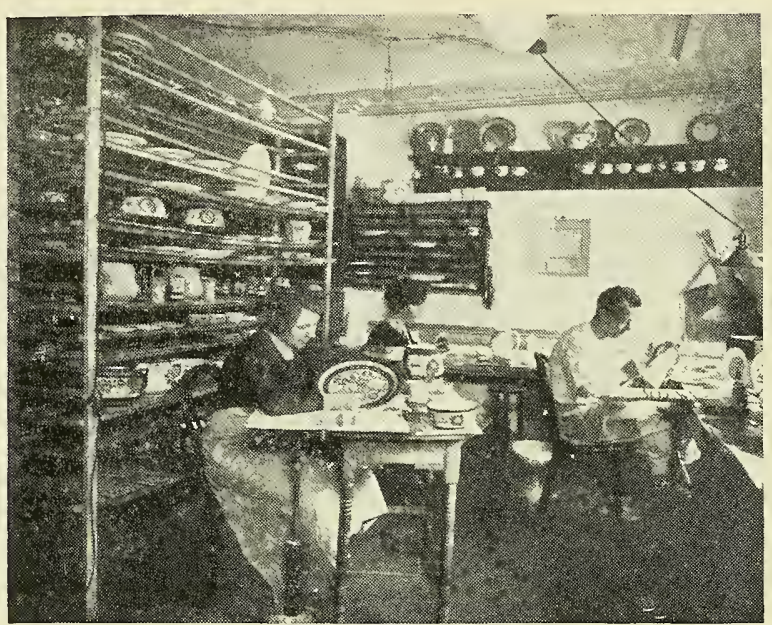

Americans from Czechoslovakia: painting pottery by hand

HE background of the Czechoslovak immigration is essentially rural. Like all Slavs, they are a race of land tillers. The bulk of the Czechs came when land was still cheap, settled in the Middle West, and there form a considerable element among our farmers. Still others entered our factories where they utilized the mechanical ingenuity which, with technical skill, is the distinguishing characteristic of Czech immigrants.

The Slovaks, on the other hand, came later and came comparatively poor. They were diverted to the mills and mines of Pennsylvania. Hardships were not new to them. They faced unflinchingly hot blasts of coke-ovens and dark depths of coal regions. This was their material contribution toward making America a conservative and prosperous land.

The other heritage which the Czechoslovaks have brought with them from their mother land is a keen sense for color, for music and for art. This influences their wage earning and social activities. Their recognition of the gifts of democracy is best exemplified by their appreciation of their adopted country.

The exhibit demonstrates the Czechoslovak part in the commerce and industry of America. Ceramics and basketry, glass blowing, pearl button making, gem cutting and polishing are represented. Their great festival of song, gymnastics and national dances is illustrative of the bright and beautiful gifts they have brought with them for America. 


\section{AMERICANS OF DANISH LINEAGE}

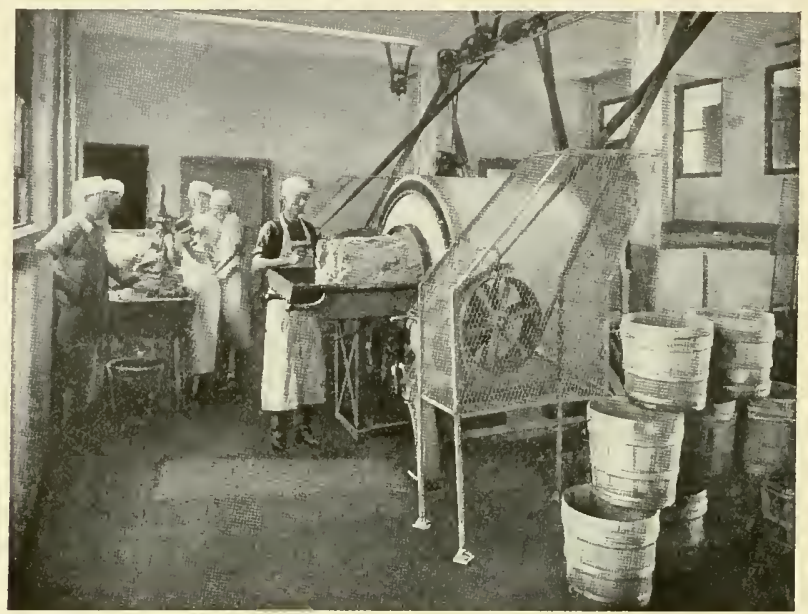

The Danish Contribution to America of Various Processes in Scientific Farming and Dairying Has Adqanced Our National Progress

ANISH participation in America's Making may be said to have been inaugurated by the world-famed Danish seamen and such famous explorers as Jens Munk and Vitus Behring, the first of whom was the discoverer of Hudson Bay and Hudson Strait in 1619, while Behring's thrilling explorations led him to the coast of Alaska during the beginning of the 18th century.

Danish officers and men served with distinction in Washington's Army. Jonas Bronck, who gave his name to the section of New York called the Bronx, and Peter Lassen, who founded the first permanent settlement in California, serve as good examples of the early Danish settlers in America.

The real influx of Danes began during the middle of the 19th Century. With Wisconsin as a center, the Danish farmers, dairymen and carpenters gradually spread throughout the West and Middle West, where by hard work and modern methods they developed huge tracts of uninhabited land into prosperous communities. The first creameries, the cow-testing association, the first cooperative dairy farming on a large scale were established by Danish farmers.

Qualities of good citizenship are highly developed in the Danish race. Recognition of this was given by Theodore Roosevelt in referring to his friend, Jacob Riis, as "The best American citizen." Intellectually and artistically, Danish culture is exemplified in America by many professional men, sculptors and artistis of Danish descent. 


\section{AMERICANS OF DUTCH LINEAGE}

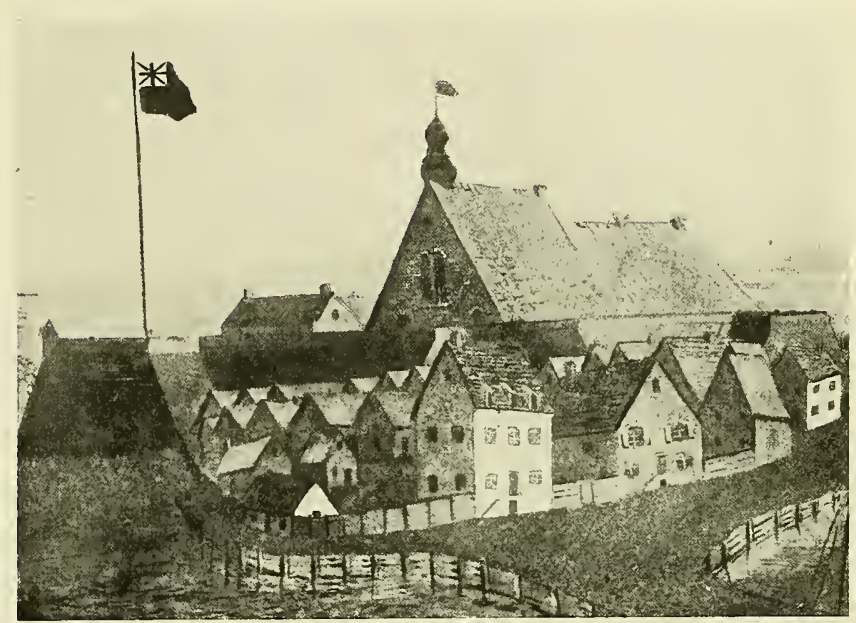

Nieuw Amsterdam had a heart. Aside from the Church and the Hospital, it provided Houses for the Doctor, the Midwife and Two Nurses

HE Dutch played an important and picturesque part in the early history of American colonization. They settled the region on New York Bay and up the Hudson River, as well as portions of Pennsylvania, Connecticut and Delaware. The largest city in the country was founded by the Dutch who called it "Nieuw Amsterdam" and left a deep imprint upon many of its sections.

Indeed the influence of Dutch immigration has been profound. To them we owe the beginnings of our public benevolence and public education, the higher education of women and that religious and social tolerance which is the basis of true democracy. Their charity was demonstrated by the provisions in their colonizing plans for adequate care of the sick and poor, the widowed and orphaned. Among the early settlers were women as well as men of culture who brought with them traditions of independence in property rights and of intellectual freedom-important to future generations. As early as $1638 \mathrm{D}$ utch settlers established the first elementary school and laid the foundation for free general education.

Many of our social customs and games have come to us through our forefathers from Holland. Our architecture has been deeply influenced by their advent and our traditions of decoration enriched. To our economic life their introduction of tile making was an addition of importance.

Today there are more than 130,000 Americans born in Holland not counting the thousands of descendants of early settlers. The majority of these later immigrants are farmers. Industries, however, also claim them, and nearly 25 per cent. of these citizens are engaged in the manufacture of Grand Rapids furniture, of silk, and diamonds. They are found as fishermen, too, established around Long Island in the oyster trade. They have made great additions to the celery-growing industry and have introduced the cultivation of tulips on a large scale. Because of their substiantial and vigorous character, immigrants from the Netherlands have always shown a remarkable faculty for assimilating the ideals of their new country, while bringing valuable gifts of industry and skill. 


\section{AMERICANS OF ENGLISH LINEAGE}

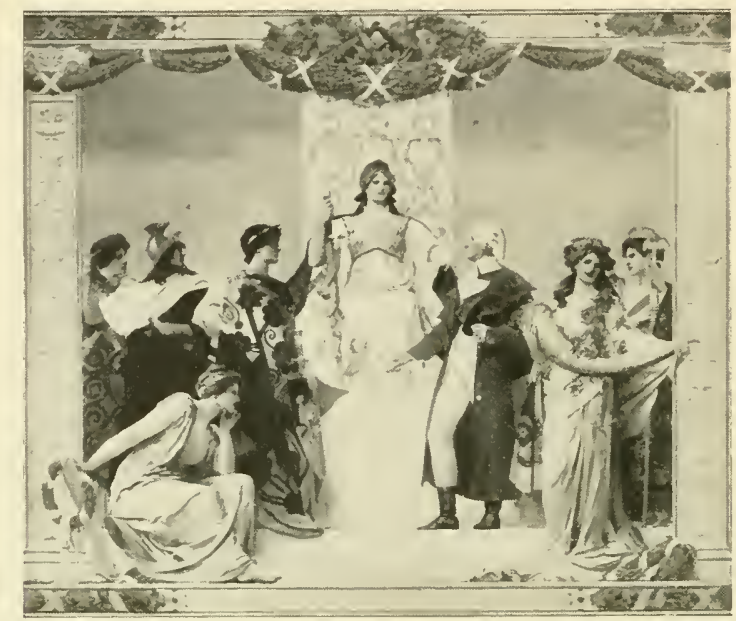

Wrashington Laying His Commission at the Feet of Columbia-Has Been Chosen as Symbol of the Superb English Spirit, $W$ hich Founded and Developed the Thirteen Colonies and Shaped the real America of To-Day

[ 1 HE English colonists contributed to American life its ground-work of language, literature, social customs, education, political and economic structure and the entire body of English law, including the system of trial by jury.

From England we got our first iron works, cotton mills and railroads. In architecture the colonists produced from the "Georgian" house an adaptation known as the "Colonial type." Our earliest musical mood was expressed by oratorios and psalmody.

The exhibit of the English section shows a life-sized symbolic statue of Law; a realistic scene of a "Town Meeting —the Foundation of Representative Government"; also an "Old-Time School Room." The symbolic and historical Pageant shows, dramatically, that the United States stands upon a foundation of English ideals and institutions.

A pamphlet has been prepared for the English section by the History Department of Columbia University, and a twenty-eight page pictorial folder traces the progress of English enterprise and ideals from the explorer, Cabot, in his quaint ship off the coast of New England down to the day of that great American of English lineage-Abraham Lincoln. 


\title{
AMERICANS OF ESTHONIAN LINEAGE
}

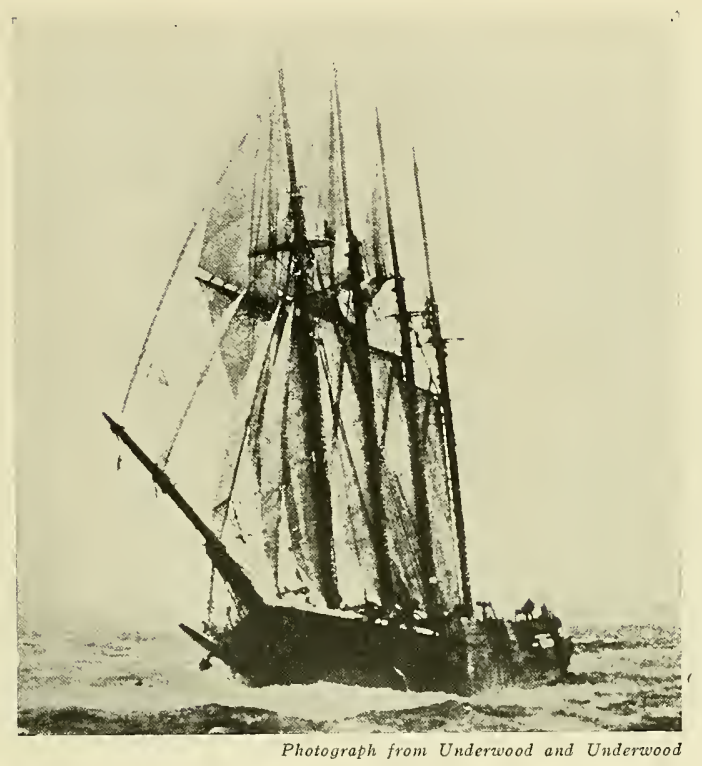

\author{
"AMERICA AHEAD!" \\ The Sea Still Calls the \\ Esthonian Who Has \\ Made America His Home
}

HE tight little country of Esthonia, consisting largely of seacoast, resting on the Baltic Sea and the Gulf of Finland, has been from time immemorial essentially a maritime nation. About thirty years ago the first immigrants from this country began to come to America.

The first of these immigrants were seamen who settled down in the large seaport cities of America. Some twenty years later farmers from Esthonia settled in the West and Northwest of America. By their efforts great stretches of land were cleared of heavy timber and made ready for the production of crops in which this group has been conspicuously successful. Americans of Esthonian lineage are also found in trades. They are iron workers, carpenters, dock and ship builders. Their outstanding contribution, however, has been on the sea. They manned and officered American ships during the World War and the majority of their workers are employed on ships.

Americans of Esthonian lineage are presenting one of the most unique of all the exhibits. A miniature dock is shown about which are moored ships from the seven seas manned by Americans of Esthonian lineage-their contribution to the prosperity of our nation. Ships in glass bottles ingeniously constructed, form an unusual scheme of decoration. 


\section{AMERICANS OF FINNISH LINEAGE}

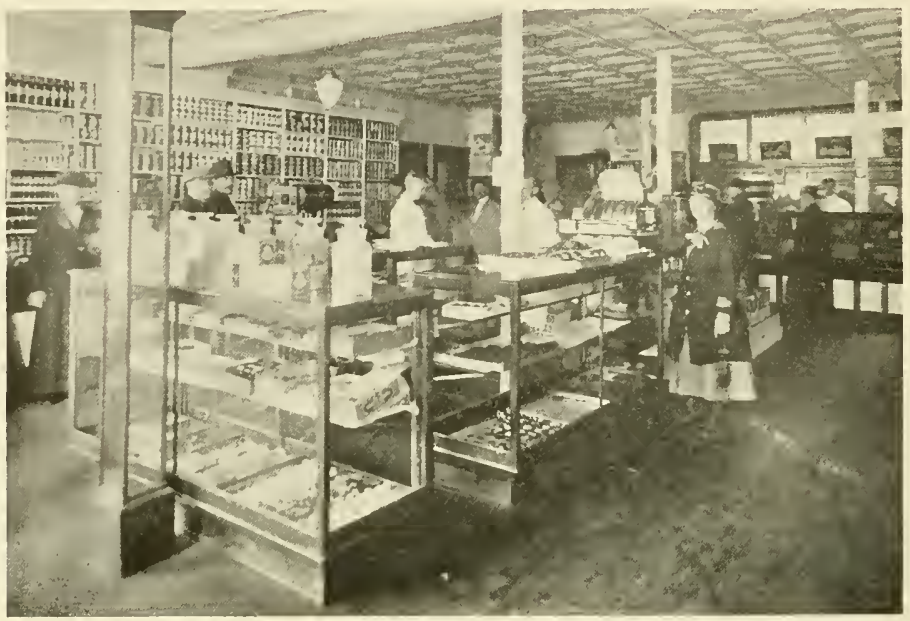

A cooperative store organized and successfully managed by Americans of Finnish descent

HE Finns are a sturdy Northern people. About twenty years ago there was considerable immigration of Finns to this country. The high-water mark for Finnish immigration was reached in 1903. According to reliable estimates, over 50 per cent. of them live in rural communities in America. Because of their strength and hardihood they are especially valuable in the lumber industry of the Northwest.

Aside from agriculture, they are employed as sailors and salmon fishers, contributing the majority of workers on the Columbia River. They are numerously represented in iron and copper mines. Women of Finnish descent constitute an important element in the cotton and linen mills of New England, and the needle trades, in New York.

Their outstanding contribution to America, however, has been in the development of cooperative organization. They have been the leaders in cooperative movements in this country, and they have organized stores, dairies, apartment and boarding-houses, and restaurants.

They have the intelligence, solidarity and traditions necessary for success in this constructive work. 


\section{AMERICANS OF FRENCH LINEAGE}

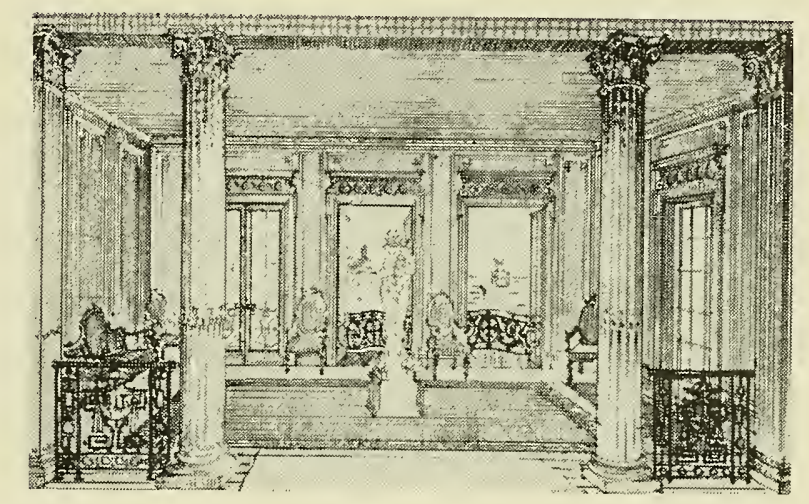

Exhibit of Americans of French lineage representing a typical mansion of Louisiana

$\mathbb{1}^{1}$

HE record of the French contribution to the upbuilding of this country begins, of course, in the period of exploration and discovery. Countless place names bear witness to the impress of this nation. Settlements by Frenchmen extended over territory now bounded by a dozen states. Later, thousands of Huguenots came to the English colonies and brought with them much that sank deep into American life.

In Louisiana especially, this Old World atmosphere was most clear and lasting. From New Orleans radiated a distinctively French influence. Its architecture, cuisine, customs and language formed one of our most cherished traditions. Here Grand Opera was early produced. This gave a definite urge to that art impulse in America. One of the important channels for l'esprit Gaulois was through Negro music, deeply affected as it was by contact with French melody.

The history of the fruit, cotton and sugar industries in the country all show interesting contributions from the French. They also did much to develop metal and gunpowder industries. In the realm of fashion and in the culinary art their leadership among us has always been unquestioned. Aside from the vast general contribution of France to all the arts-painting, sculpture, architecture, the drama and language which America shares with all the civilized world, there have been many artists and eminent scientists of French origin whom we may claim as citizens.

The French exhibit is designed to show their early settlements of Louisiana, indicated by the representation of a room in an early French mansion in New Orleans. The whole impression is of the culture and good taste which is the outstanding contribution of this race to America. The program of tableaux demonstrates the French place in American history from the adventures of intrepid explorers and fighters to the gay whirl of a fashion parade, concluding with the ever-thrilling representation of "Liberty Enlightening the World." 


\section{AMERICANS OF GERMAN LINEAGE}

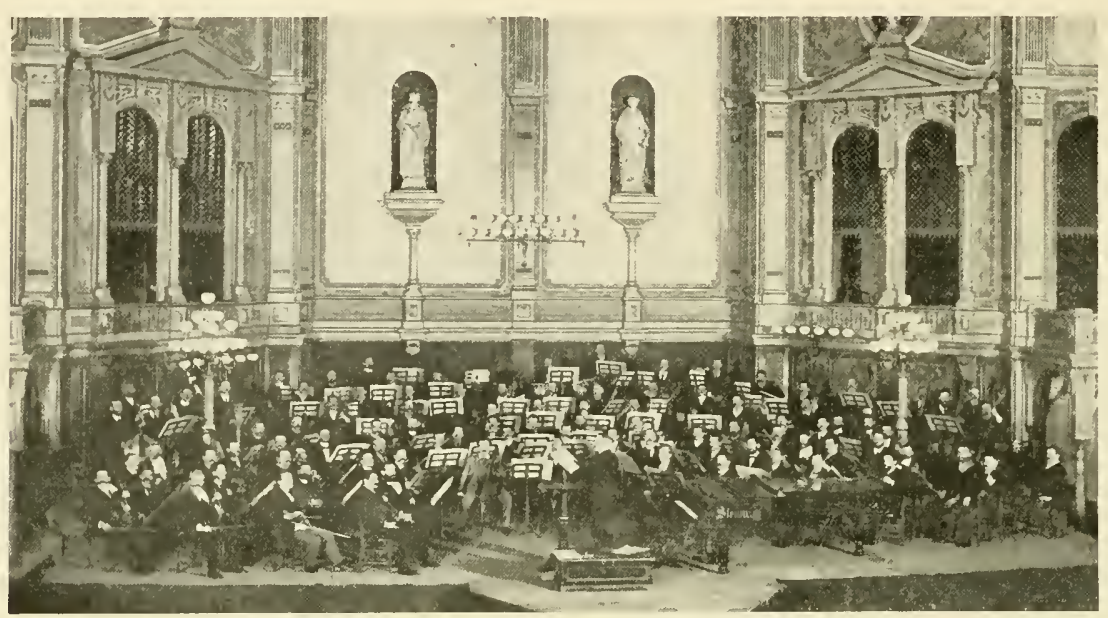

"Probably no foreigner ever exerted such widespread influence on national musical taste in America in modern days as Theodore Thomas."-(Elson.)

SP HE great gifts of German immigrants to America are science and music. Nevertheless they have had an important share in building up this nation. From Colonial days these Americans have entered into our institutions and held a place in our history.

They registered the first protest against slavery and won for the press a freedom unknown before their efforts in the middle of the 18th century. German immigrants helped to settle the Middle West and in the far West they were pioneers who bore the brunt of many an Indian raid. In the revolutionary war German settlers gave distinguished generals to the service of Washington. The famous Mollie Pitcher was of German origin and her bravery was typical.

In the Civil War the Germanic element in United States was important in bringing up the Anti-Slavery balance and in steadying sentiment in border states.

Many pioneer industries were opened up by German immigrants, such as paper manufacturing, iron foundries, glass blowing and the plants which were forerunners of our great steel mills. Many inventions which resulted in improved processes were made by Americans of German descent.

German influence on education in this country is unquestioned, the kindergarten and athletics are two definite additions to the original system of public education. A great many artists, distinguished in painting, and sculpture, are of German origin. Other Americans, engineers, journalists and statesmen whose ancestors came from Germany have made great gifts to America. But the greatest of their cultural contributions were in music, which have influenced America profoundly. 


\section{AMERICANS OF GREEK LINEAGE}

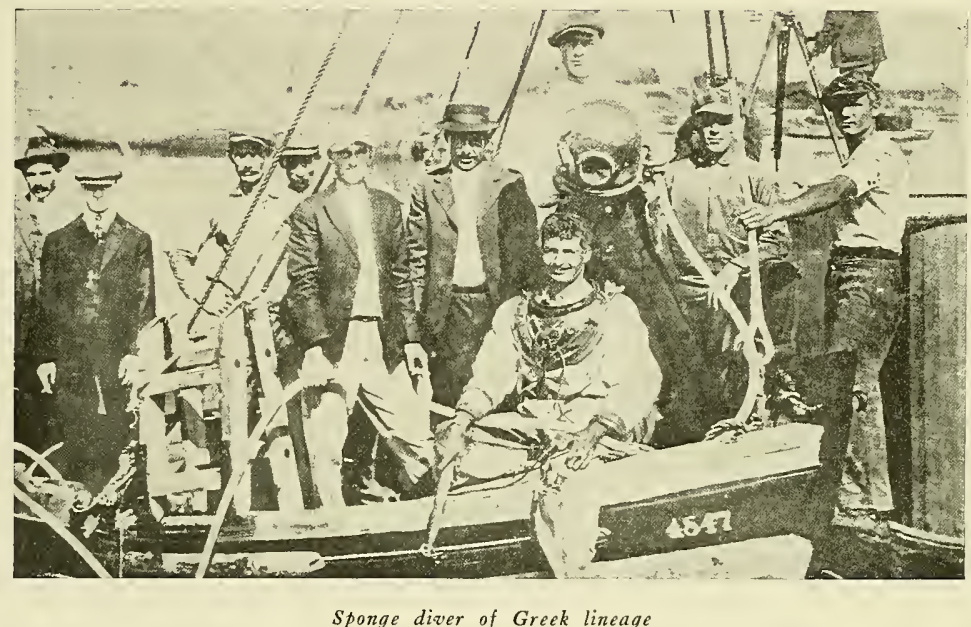

ת1

$\mathrm{HE}$ achievements of classic Greece are the common possession of the civilized world and are inwrought into its cultural life. Its architecture has been the inspiration of structures in every city.

Greek immigration to America, although it has only assumed large proportions in the past fifteen years, has already resulted in important contributions to American economic life. Americans from Greece are at work in the textile mills of New England and in the mines of the West. They share in the moving-picture industry. They are running hotels and restaurants and are employed as waiters and cooks.

Individual enterprises characterize these Americans of Greek Lineage. Our shoe-shining parlors are largely in their hands. Through their little stands they market California fruit. Their candy stores and "patisseries" are part of our national enjoyment. One of their greatest successes has been in the florist business. Cigarette manufacture has been widely developed by them. Along the New England coast Greek-born Americans are engaged in lobster fishing and on the coast of Florida in the sponge industry. Furriers from Kastoria in Macedonia introduced important processes which they themselves originated such as the piecing together of small skins to form garments.

The Exhibit of Americans of Greek lineage tells of the sponge industry. The workers are typified by a diver with full equipment. Furriers and cigarette makers give daily demonstrations of their trades. The contribution of Greek florists to America is presented in a tableaux of Athena's Gift of Flowers - an integral part of their elaborate festival program which recalls the heritage of beauty from Ancient Greece while demonstrating the gift of modern Greeks to the country of their choice. 


\section{AMERICANS OF HISPANIC LINEAGE}

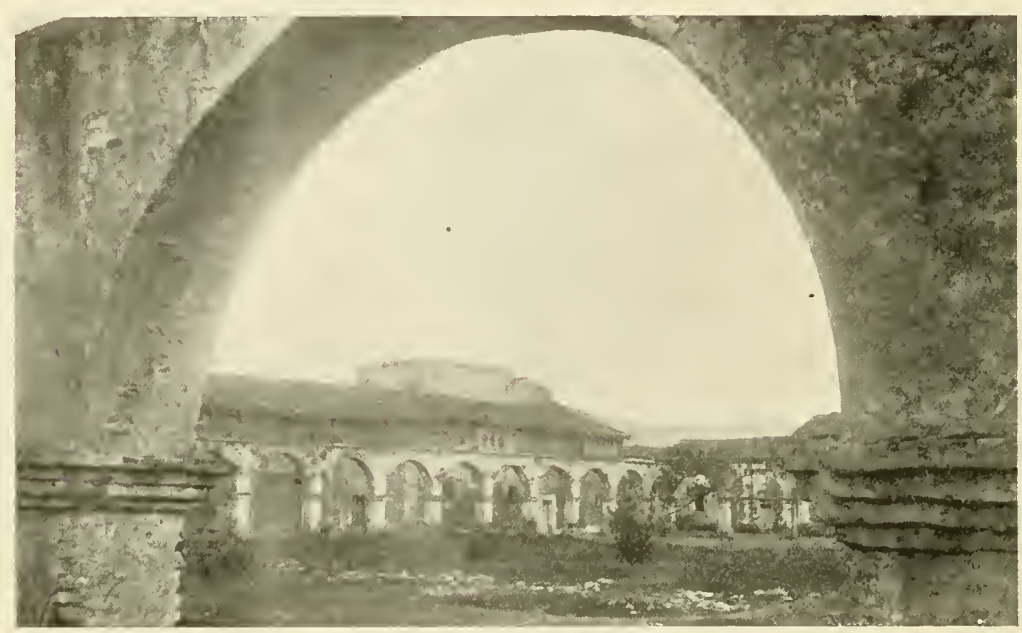

Mission of San Juan Capistrano

ISPANIC influence in America originated in the vast territories of the South, Southwest and West of the United States which were first explored by Spaniards. Florida, New Mexico, Arizona, Texas and California were first settled by them. San Augustin was their first permanent settlement in America and is one of its oldest towns.

Spanish Missionaries were making history in the Southwest and West of America as early as the 16th and 17th centuries. They founded Missions, housed in beautiful cloistered structures which became garden spots of service. Their educational work among the Indians included training in better methods of agriculture and in higher standards of personal living. To these missionaries we owe the preservation of Indian dialects.

Later Hispanic immigration has come from Spanish America as well as from Spain. In 1920 such immigrants numbered 18,821. To-day our citizenship includes nearly half a million Americans of Hispanic lineage. The chief contributions of this group to commerce and industry are methods of irrigation, cattle breeding and fruit raising. The Spanish were the first to import horses and burros used along the coast. They also introduced all the chief fruits of California. Their coming had a profound effect upon the customs, speech and architecture of the Southwest. The "mission" type of furniture has been widely popularized. The characteristic Spanish structure involving open courts, tiled roofs, arched corridors, the use of cupolas, towers and belfries, is the dominant style of building in the west.

Two phases of the contribution of Americans of Hispanic descent to this country are worked out in their Exhibit, -early exploration and settlement. 


\section{AMERICANS OF HUNGARIAN LINEAGE}

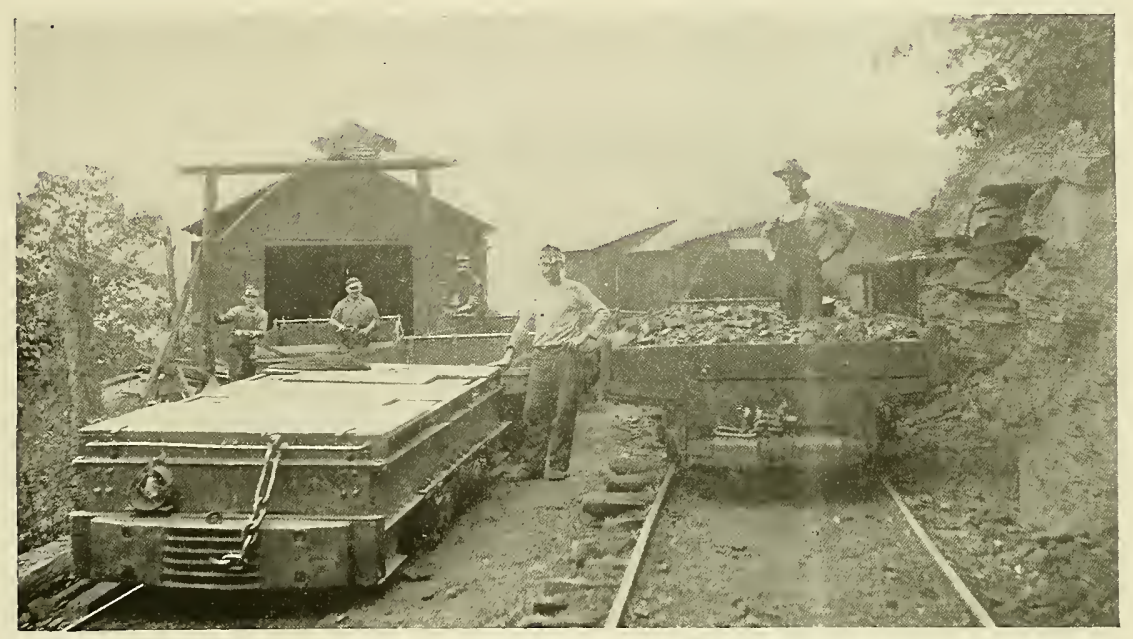

Coming up from the mine-a typical industry of Americans of Hungarian descent

MMIGRATION from Hungary started about 70 years ago, when, after the war of liberation of 1848, political refugees from that land sought a home in the United States.

The first Hungarian immigrants found employment in mines and factories and in the agricultural districts of California. It was they who introduced the grape industry so intensive to-day on the shores of the Golden Gate. Their skill in military science was a welcome gift during the Civil War and many Hungarian-born soldiers rose to high rank.

In 1870 the real flow of immigration from Hungary began. It furnished a great quantity of valued labor to factories and mines. Hungarian genius did much to develop the motion-picture industry and directs some of the most successful of the large agencies.

In the arts of literature, drama and music, Americans of Hungarian birth have made distinguished contributions. The New York $W$ orld was founded by a citizen of Hungarian birth. Hungarian opera singers, actors and playwrights have secured prominent fame in their adopted country. Hundreds of Hungarian-born musicians play in our orchestras. In the high ranks of architecture, medicine and engineering are found these Americans from an older world. More than 2,000 sick-benefit societies established by them testify to their feelings of charity. Above all, however, they take pride in the loyalty, industry, perseverance and obedience to law which are the fundamental characteristics of their race.

The exhibit of Americans of Hungarian lineage features a pictorial map showing their distribution and principal activities. Enlarged photographs illustrate their contribution of art and industry. Embroideries and craft work offset the representations of the vast drama of their unskilled labor. 


\section{AMERICANS OF ICELANDIC LINEAGE}

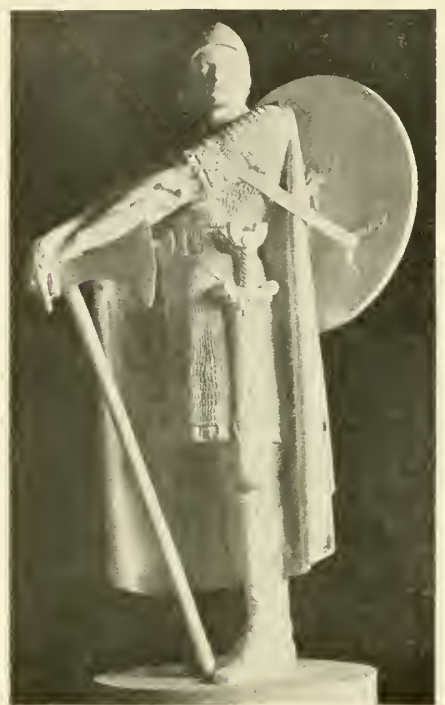

By Jonsson, Fairmount Park, Philadelphia

\author{
FIRST EUROPEAN SETTLER \\ ON THE NORTH AMERICAN \\ CONTINENT
}

DVENTURERS from Iceland play a colorful part in the earliest traditions of the American continent. They formed part of that daring group of Norsemen who wrote the opening chapters in the story of America's Making.

It was not, however, until the latter part of the 19th Century that the Icelanders entered the stream of American immigration. Stimulated, perhaps in some degree, by the effort of the Department of State in Grant's Administration to attract them to colonization in Alaska, a number of Icelanders joined in the gold rush to that section. The majority of them however, have made settlements in Minnesota and Dakota. A few are found in Utah and Washington.

The dreams which these people of the far North brought with them were not for wealth or fame. What they desired was to become scholars and literary men, lawyers, statesmen, artists. In view of the fact that less than fifteen thousand people of Icelandic descent inhahit the United States, a surprising proportion of them have become prosperous. They are largely engaged in agricultural pursuits, although a few of their number are found among the fishermen of Gloucester and other seaports.

"Farmers of Icelandic Descent from the Middle West" is one of their principal exhibits. Here is shown a miniature farming comnunity. It is a graphic representation of the transmission of the Icelandic farmer to America and his contribution to our food production. The spirit of the Vikings still persists in these Americans. The exhibit presents as witness of it evidences of their early explorations. Fishing and shipping activities are also shown. A statue by Jonsson represents the art of Ireland, an exhibit of needlework, its craft. 


\section{AMERICANS OF IRISH LINEAGE}

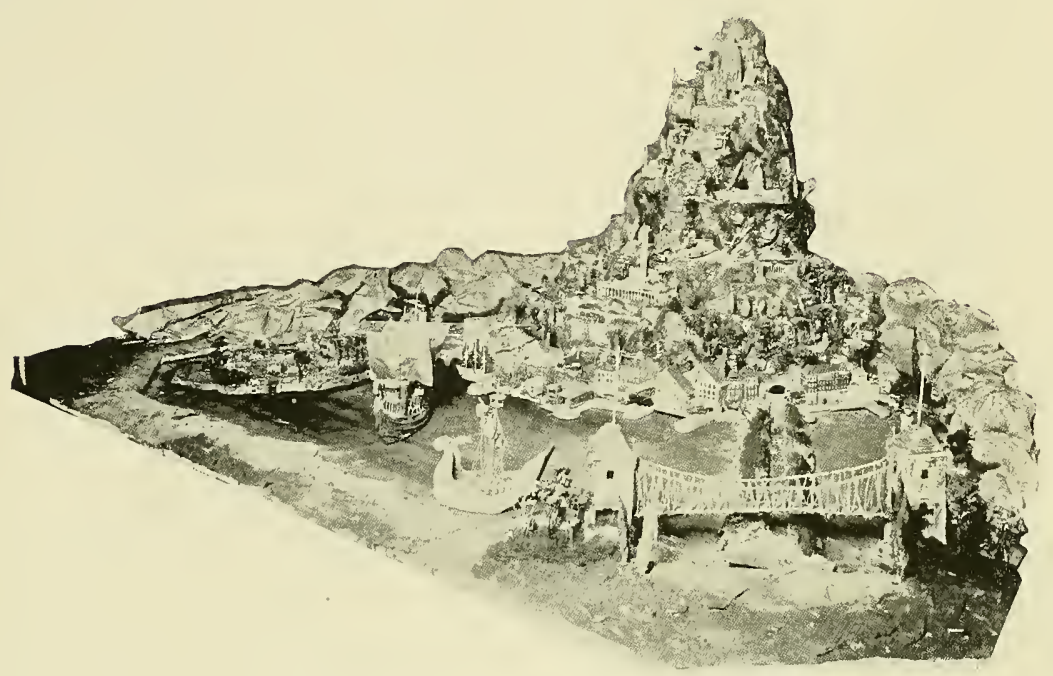

Model of the Exhibit of Americans of Irish descent

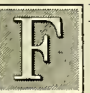

ROM Colonial days Irish immigration has been one of the active and important elements in America's making. Before 1650 Irish settlements were numerous in New England and the South. James McBride preceeded Daniel Boone by fifteen years to Kentucky, and other pioneers explored Utah and Oregon. Americans from Ireland were prominent in the military history of America and Commodore John Barry was "Father of the American Navy."

After 1830 the vast number of Irish immigrants increased the population enormously, and from the beginning of the nation contributed sagacity and organizing power to public administration. Some lfty Governors in the United States claim forebears from the Emerald Isle. Eloquent in debate, the Americans of Irish descent have always been in the fore of political activity, and have given numerous men of distinction to our bench and bar. Their brawn and brains have helped to build the railways that opened up the continent. By invention and distribution of harvesting machinery they have made vast agricultural territories productive on a grand scale.

The Irish race has profoundly influenced our journalism, not only through their great editors, but through their large representation in the rank and file of the profession. They have made distinctive contributions to literature and the drama. Irish ballads are among our most popular songs and Irish jigs and dances are the outlet of many a child in school and playground. The versatility and buoyancy of the American temperament with the sporting instinct to take chances are evidences of the Irish strain in our blood.

The exhibit of Americans of Irish lineage shows by a symbolic structure the varied contributions of the race to this country. A mountain ten feet high has at its base water in which such inventions as the submarine and steamboat are shown by floating boats. Miniature buildings along the shore illustrate industrial contributions. A Hall of Fame shows noted individuals contributed by Irishmen to America, while mounting the slopes of the mountain are historical scenes and models which portray their cultural gifts to this country. Their basic contributions are also shown in their festival program. 


\section{AMERICANS OF ITAIIAN LINEAGE}

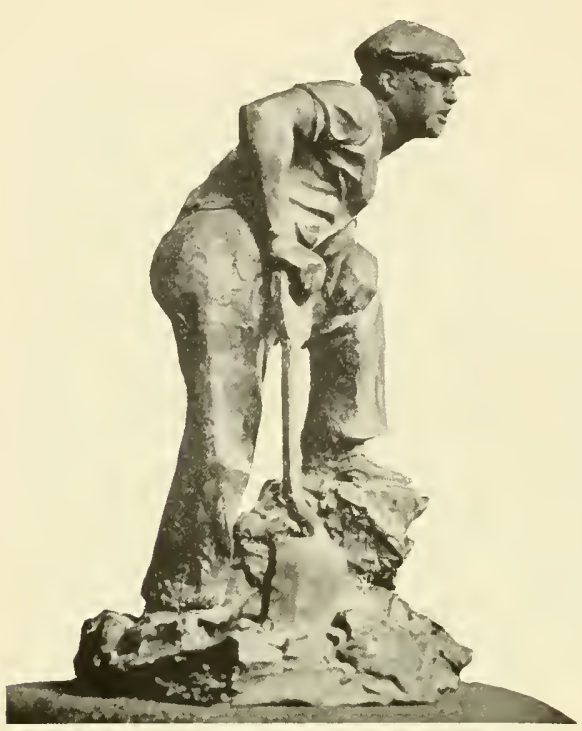

By Vincent Salerno

\author{
BUILDING AMERICA! \\ A Symbolic Figure Representing \\ the Essential Italian Contribu- \\ tion of Mass Labor
}

TALIANS first opened the New World to Old World settlement by the expeditions of their explorers-Columbus, Vespucci and Verrazano. And from their "lovely land" they have brought offerings which have added to the immense cultural inheritance which America received from the Italian Renaissance.

Our musical education during the first half of the nineteenth century was almost exclusively in the hands of Italian teachers. Our supremacy in opera is due to the artistry and genius of Italians. In painting, sculpture and drama the influence of Americans of Italian heritage is profoundly exerted upon our art.

A vast amount of unskilled labor has been available to America from Italian immigration. These Americans of Italian lineage have furnished a great percentage of the mobile and seasonal labor for construction of public works, railroads and highways. They also engage in such industries as cotton, tobacco and garment manufacture. Their restaurants with the flavory food of Italy have been conspicuously successful. In their hands rest the importation of fruits, oils, cheese and other food commodities prepared in Italy. Large numbers of this group engaged in agriculture, show a preference for specialized crops, such as fruits, berries and truck gardening. Their work in the sugar, cotton and tobacco fields of the South is becoming increasingly important.

The sunny temperament of the Italian and his response to the colorful aspect of life are potential influences upon American character.

The arrangement of the exhibit of Americans of Italian lineage, in the form of an Italian garden with pergola, fountain and flowers, creates the impression of the decorative quality of the contribution of this group. What it has given to agriculture and industry is suggested pictorially on a large map of the United States and symbolized by a statue of a laborer. Its music is gloriously represented by the festival program of grand opera sung by artists of note. 


\section{AMERICANS OF JUGOSLAVIC LINEAGE}

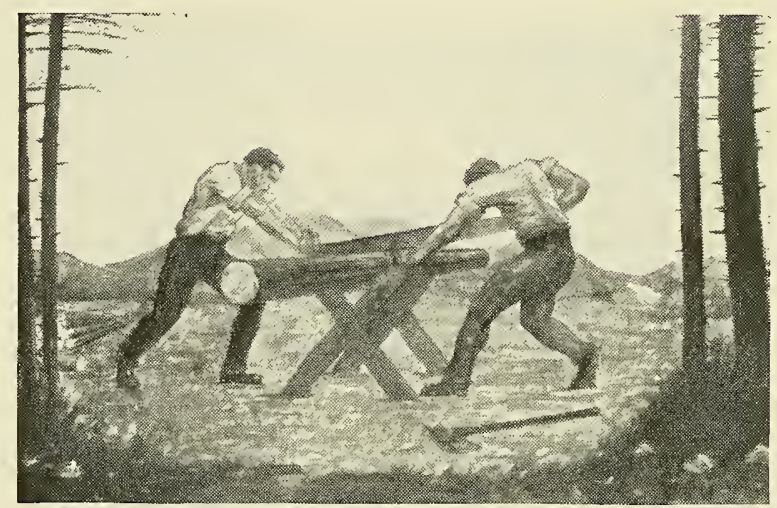

Panel of Lumbermen from Jugoslav Exhibit

UGOSLAV is the collective name of the three kin Southern-Slav racial groups, now politically united in the new Kingdom of the Serbs, Croats and Slovenes, known also under the name of Jugoslavia.

The first Jugoslavs to tread American soil at the beginning of the 18th Century were Dalmatians, a sturdy race of sailors, who, as a result of exploration made the first map of California. In Northern Michigan a number of Slovene missionaries were active pioneers in the early 19th Century. The most famous of them, Bishop Baraga, translated part of the Bible and edited a dictionary in the Chippewa language.

However, the mass of Jugoslav immigration arrived after 1880, and most of it since the beginning of this century. Now their number can be estimated at about 700,000 including both first and second generations. Croats compose the larger number. Slovenes come next with more than one-sixth of their entire number in America. Last come the Serbs.

The Jugoslavs in America in overwhelming majority are workers in mines and mills, especially in coal and iron mines and in steel mills. In lumber camps they are employed as husky workers. In California they have succeeded as prominent fruit growers and fishers. Indeed part of the fisheries are controlled by them. Oyster growing in Louisiana is to some extent the exclusive trade of these Americans and elsewhere in the South the manufacture of "French" staves in their exclusive industry. Dalmatian sailors are found on practically every American ship. Aside from some individual noted for important inventions, it is this vast and varied labor which is the great contribution of Jugoslavia to America.

A fruit orchard model and a model showing the catching of tunafish are the chief features of the Jugoslav exhibit. Improvernents of the wireless telephone demonstrates the invention of Professor Pupin. A decorative frieze depicts the outstanding gifts of this group to its adopted land. 


\section{COMMITTEES REPRESENTING RACIAL GROUPS IN AMERICA'S MAKING}

\section{AMERICANS OF ARMENIAN LINEAGE}

Rev. M. T. Kalaidjian, Chairman Dr. A. Constantian

AMERICANS OF BELGIAN LINEAGE HONORARY COMMITTEE

His Excetlency Baron E. de Cartier de Marchienne, Betgian Ambassador at Honorable Pierre Mali, Belsing Con,

EXECUTIVE COMMITTEE

Rt. Rev. J. F. Stillemans, Chairman Jehin J. de Prume, M.D.
Rev. O. A. Nys

$\begin{array}{lll}\text { Rev. O. A. Nys Rev. C.C. Roosens } & \text { Henry Bayer } \\ \text { Pierre Danco } & \text { Leo Garcey }\end{array}$

AMERICANS OF CARPATHO-RUSSIAN LINEAGE $\begin{array}{ll}\text { E. I. Tziorogh, Chairman } & \text { Miss S. N. Olshanskaya, Secretary } \\ \text { Rev. J. Krohmalney, Vice Cliaiman } & \text { S. F. Rubas, Treasurer }\end{array}$

P. P. Hadik, Secretary

WOMEN'S COMMITTEE ADVISORY COMMITTEE

$\begin{array}{ll}\text { Very Rev. A. Philippovsky Mr. I. Zylich } \\ \text { Mr. M. H. Bormch } & \text { Mr. S. D. Zavorotiuk } \\ \text { Mr. V. Varcholak } & \text { Mr. N. K. Hladun }\end{array}$

Mr. D. Sysak

Mr. J. P. Karlak

Mirs. I. V. Tziorogh

Mrs. M. Zacharko

E. I. Tziorogh, Concert Director

J. H. Boruch, Choirmaster of the Carpatho-Russian Choir of Passaic

J. I. Komas, Choirmaster of the Carpatho-Russian Choir of Yonker
I. II. Boruch, Program Director AMERICANS OF CZECO-SLOVAK LINEAGE

Dr. Borivoj Prusik, Honorary President Hon. Dr. B. Stepanek. Protector Mrs. Thomas Capek, President Kev. L. A. Engler, Yice-President

Mrs. Albina IIlavac, Vice-President Mr. Jar. Jakoubek, Secretary
Mrs. M. Zgurns, Treasurer for Slovaks Mr. Jos. Jodr Treasurer

\section{EXECUTIVE COMMITTEE}

Mr. Karel Leitner Mr. Clement Thrisky Rev, L. A. Engler Mrs. M. Simek COMMITTEE ON FINANCF

Mr. Frank Hucl, Chairman Mr. J. Havlik, Secretary Mr. M. Otruha Mr. Jar. Simon Mrs. M. Bronk Mrs. A. Hlavac Mrs. M. Mergh Mr. C. Ruman Mr. J. Tomes Mr. M. Gazak Mr. J. Zguris
Mrs. M. Macucha Mrs. M. Simek Mrs. A. Hala COMMITTEE ON PUBLICATIONS

Rev. L. A. Engler, Chairman Karel Leitner Mr. V. B. Tuma PUBLICITY COMMITTEE

Mr. Karel Leitner, Chairman Mr. Mr. V. B. Tuma Mr. L. Kozar COMMITTEE ON EXHIBITS

Prof. Sarka Hrbkova, Chairman Mr. Engelbert Svehla, Secretary

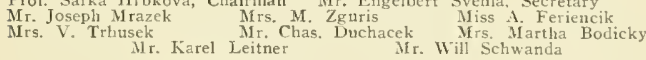
SUPERVISORY COMMITTEE

$\begin{array}{lll}\text { Mrs. Marie Zguris, Chairman M. M. Kazak Mrs. Libuse Motak } \\ \text { Mr. L. Kozar } & \text { Mr. I. Jancek Mr. Surovy }\end{array}$ COMMITTEE ON MUSIC

$\begin{array}{ll}\text { Mrs. Marie Mergl, Chairman } & \text { Mr. Clement Ihrisky } \\ \text { Mr. Rudolph Prusa, Director } & \text { Mr. J. Jedlicka }\end{array}$ COMMITTEE ON PROGRAM (Racial) $\begin{array}{ll}\text { Mr. Joseph Gregor, Chairman Mr. R. Velk } & \text { Mr. J. Slarik } \\ \text { Mr. J. Androvic } & \text { Mr. V. Krejcik Mr. C. E. Hrhek }\end{array}$ AMERICANS OF ENGLISH LINEAGE Rev. Herbert Shipman, D.D., Bishop-elect, Honorary President
Dr. Louis Livingston Seaman, President Walter B. Tufts, Secretary N. Devereaux Putnam, Vice-President and Treasurer

\section{EXECUTIVE COMMITTEE}

Louis Annin Ames above ofticers, also

Mrs. C. R. Scarborong
Mrs. Louis Livingston

Miss Ruth Lawrence Wayne W. Wilson

\section{PAGEANT COMMITTEE}

Mrs. Ernest H, Bennett, Chairman Mrs. Edward G. Marks

General Reed, U. S. A. Discon Fox Mrs, C. R. Scarborough

John W. Leighton Mrs. Oswald Yorke Oswald Yorke

Mrs. Wm. Robison H. Gloster Armstrong Rev. J. P. McComas, D.C.

$$
\text { EXHIBIT }
$$

Mrs, C, R. Scarborough, Chairman Mrs, C. J. Goddard Shaw Henry F. Bultitude John W. Dunsmore Mrs. F. C. Hodgson Reginald P. Bolton Dr. Edward H. Hall Joseph H. Hum Alrs, Sarah Sangster MINANCE
FINAN,

C. S. LePoer Trench, Chairman Lonis Annin Ames

Rupert S. Highes Dr. Louis Livingston Seaman Mrs. Edward G. Marks, Chairman F. H. Kinnicutt Wayne W. Wilson
AMERICANS OF ESTHONIAN LINEAGE

Rey. C, Klemmer, Chairman Albert Somnie, Treasure

EXECUTIVE COMMITTEE

Jacob Lacht Constantin Flink Hugo Sallo AMERICANS OF FRENCH LINEAGE

Lucien Jouvaud, Chairman André Prost, Secretary FINANCE COMMITTEE

Theo. Seltzer. Chairman Henry Blmm Enile Rey Pierre Cartier Fëlix Wildenstein COMMITTEE ON LITERATURE, DRAMA AND PUBLICITY Prof. Chas, A. Downer, Chairman Prof. Auguste George Prof. John Erskine Prof. Brander Matthews André Prost COMMITTEE ON ART AND INDUSTRIAL EXPOSITION Hon. McDougall Hawkes, Chairman Y, Sanford Saitus COMMITTEE ON ARCHITECTURE AND DECORATION J. H. Freedlander. Chairman Cbarles Butler Whitney Warren Henry R. Sedgwick Lloyd Warren

COMMITTEE ON PAGEANT AND ENTERTAINMENT Réné Wildenstein, Chairman André Prost, Secretary Jules Bouy
Engene Chauvin André Chotin Engene Chanvin Condé Nast

COMMITTEE ON HISTORY

Dr. George F, Kunz, Chairman Victor Hugo Palltitts Alexander J. Wall AMERICANS OF GREEK LINEAGE

Chairman: George Caranicholas Treasurer: Joln Sarantis

Vice-Chairman: Prof. Carrol Brown Secretary: Hichael Theodoropoulos ice-Clairman: Dr. Alex Alexion Dr. George Papanicolaon A. Gerakis EXHIBIT COMMITTEE Rev. Dr. Thomas J. Lacey, Chairman Nicholas N. Mavrogenis A. Condos
Rev, D. Callimahos
Rev. V. B. Darlington PAGEANT COMMMITTEE Mrs. D. Callimahos, Chairman Mr's. Feramoaca Mrs. Marie Economidy
Mrs. Corinne Canoutas AMERICANS OF HISPANIC LINEAGE

Senora R. M. deMorrison, Chairman Phanor J. Eder, Treasurer Humberto Arias, Secretary and Treasurer COMMITTEE

Ishmael Smith Luis Mora A. B. Aviles y Senora Evangelina Antay Viclal Rafael Sala Matilde de Cordova AMERICANS OF HUNGARIAN LINEAGE

GENERAL COMMITTEE
Father Stephen Czernitzky, Chairman William Mayer, Secretary Iiss Alice Kauser, Treasurer, Chairman of Pageant FEDERATION OF HUNGARIAN CLERGY Rev. Alex, Kalssaay, President Rev, Lewis Nanassy, Secretary AMERICANS OF ICELANDIC LINEAGE

Chairman, G. G. Gudmminon AMERICANS OF IRISH LINEAGE OFFICERS AND EXECUTIVE COMMITTEE Col. Timothy J. Moynahan, Chairman John McKee, Treasurer iss) Katlleen M. Kemmy, Secretary Hichael J. O'Brien, Historiographe Liwrence J. Rice Iartin Conboy Pat'k A. Maynor Rt. Rev. Afonsignor Jos. Smith GENERAL COMMMITTEE

(Miss) Maura Fitz Gerald (Miss) Catherine Ledwith $\begin{array}{lll}\text { Timothy Ryan } & \text { Martin Waldron } & \text { (Miss) Helen L. Lee } \\ \text { Michael White } & \text { Ios. J. Moynahan } & \text { Edmund Kelleher }\end{array}$ Michael white Joln F. O'Loughlin Jos. Carroll Frank Flaherty Lonis P. Robinson Mrs, M Gearon Irs, Helen Cusack Mrollie ilurphy FINANCE COMMITTEE Pat'k A. Moynaban SUB-COMMITTEE ON FINANCE

Pat'k J. Barrett Daniel O'Connor Michael J. Farley Michael Healy PUBLICITY COMMITTEE

Dennis Coughlin, Chairman Seamas O'Sheel COSTUME AND PAGEANTRY COMMITTEE

$\begin{array}{ll}\text { Miss Sarah McKelvey, Chaiman } & \text { Thos. Hennessey } \\ \text { Major John C. O'Reilley } & \text { Monsignor Jos. Smith }\end{array}$

PERMANENT EXHIBIT AND BOOTH DECORATION COMMITTEE

Joln J. Sheridan, Artist Capt. Thos. Tuite Pat'k J. Reilly AMERICANS OF ITALIAN LINEAGE EXHIBIT COMMITTEE

Paola S. Abbate Victor Salvatore, Chairman
Attilio Picirilli Vincent Salerno $\begin{array}{lll}\text { Vincenzo Meserendino Ottilio Picirilli } & \text { O. Ruotolo } & \text { Vincent Salerno } \\ \text { Vint Tamburini }\end{array}$ PAGEANTRY COMMITTEE BOOTH COMMITTEE Mary A. Frasca, Chairman Dr. Vincent Giliberti, Chairman 


\section{COMMITTEES REPRESENTING RACIAL GROUPS IN AMERICA'S MAKING-Continued}

COSTUME COMMITTEF

Madeline Grande, Chairman

RESEARCH COMMITTEE

$\begin{array}{lll}\text { Dr. Vittorio Racea, Chairman } & \text { Prof. C. Byrnes } & \text { Dr. F. Ettari } \\ \text { Prof. Baberis } & \text { Dr. M. E. Cosenza } & \text { Marie Frugon }\end{array}$

COMMITTEE ON MAP OF AGRICULTURE

(Italians in Agriculture)

$\begin{array}{ll}\text { Louis Forgione, Chairman } & \text { Dr. John H. Mariano } \\ \text { Dr. Paolo De Vechi } & \text { G. Rossati }\end{array}$

COMMITTEE ON STEREOPTICON SLIDES (Italians in Industry)

Dr. Paolo De Vecchi Dr. M. E. Cosenza G. Rossati Cav. G. B. Vitelli COMMITTEE ON TABLETS

$$
\text { Dr. Sante Naccarati }
$$

COMMITTEE ON HISTORY

Dr. M. E. Cosenza Dr. F. Ettari Dr. John H. Mariano F. R. Serri COMMITTEE ON MEMBERSHIP Lois Forgione, Chairman

COMMITTEE ON PUBLICITY

Mario De Biasi Paul F. Frabbito, Chairman George Tanzola

PROGRAM COMMITTEE COMMITTEE ON USHERS

Mario De Biasi, Chairman Dr. Vincent Giliberti, Chairman AMERICANS OF JUGO-SLAV LINEAGE EXECUTIVE COMMITTEE

John J. Grgnrevich, Chairman Prof. Dr. M. S. Stanoevic

Rainer F. Hlacha, Vice-Chairman Ivan Mladineo, Secretary

Dr, A. H. Mooney, Vice-Chairman D. B.

FINANCE COMMITTEE

Frank Lupsa Artur Nikoloric, Chairman Leopold Sorger

EXHIBIT AND ART COMMITTEE
Leo Zakrajsek, Chairman Mrs. Helen Arguello
Mrs. A. Nikoloric

PUBLICITY COMMITTEE

Dr. Jozo Poduje, Chairman

Rainer F. Hlacha Ivan Mladineo Prof. Dr, M. S. Stanoevic FESTIVAL COMMITTEE

Ign. Hude, Chairman John Konean akrajsek J. Cvetkovich

Mrs. Anna Mladineo Miss Ursula Zakrajsek MI Ms Mimi Dercar
V. Ujeich Hinko M. Sginppa-Zupa B. B. Rados Emilij Blazevich

\section{AMERICANS OF LATVIAN LINEAGE}

EXECUTIVE COMMITTEE

Charles Carrol, Vice-Chairman Neumann, Chairman

John W. Ozols, Secretary Charles Newman, Asst. Secretary FINANCE COMMITTEE

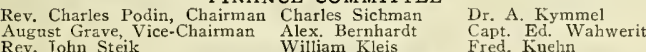
$\begin{array}{lll}\text { August Grave, Vice-Chairman Alex. Bernhardt } & \text { Capt. Ed. W } \\ \text { Rev. John Steik } & \text { William Kleis } & \text { Fred. Kuehn }\end{array}$

PAGEANT COMMITTEE

Mrs. A. Bernhardt, Chairman Mis, Charles Cooyman

Mrs. Emily Podin John Birsneek
Jrs, Otilie Kleis EXHIBIT COMMITTEE

Albert de Leon, Cbairman. Ernest Jansen, Vice-Chairman

Emma Burns August Grave Ans. Meschlauk Mrs. D. Lassma

Sporr A. Menert

PUBLICITY COMMITTEE
John Kweetin, Chairman Jacob Slave, Vice-Chairman Ernest Stahl
Andrew R. Drawneek Chas, Carrol John Birseneek Chr, Rahwin

Andrew R. Drawneek Chas, Carrol John Birseneek Ch

GENERAL COMMITTEE

Jurgis Tumasonis, President
M. J. Sadeckas, First Secretary Miss K. Karpiute, Second Secretary FINANCIAL COMMITTEE

$$
\begin{aligned}
& \text { FINANCIAL COMMITTEE } \\
& \text { L. Simutis P. S. Vilmont J. Ginkus }
\end{aligned}
$$$$
\text { COMMITTEE OF PROGRAMS }
$$

$\begin{array}{ll}\text { J. Maciulis } & \text { K. Karpinte } \\ \text { V. Sirvydas }\end{array}$

AMERICANS OF NEGRO LINEAGE EXECUTIVE COMMITTEE

James Weldon Johnson, Chairman
Eugene K. Jones, Executive Chairman Mr. Jesse O. Shipp, Assistant Louise R. Latimer, Secretary Mr. Alfred W. Ross, Orchestra Leader Harry H. Pace, Treasurer Miss Annie L. McCary, Exhibit Director Mrs. Daisy Tapley, Festival Director Lonise R. Latimer, Assistant ACTIVE EXECUTIVE COMMITTEE MEMBERS

Mrs. E. F. Horne Miss Minnie Brown James H. Hubert

Miss Anna C. Hawley Gerald F. Norm
Miss M. E. Butler

\section{AMERICANS OF NORWEGIAN LINEAGE}

EXECUTIVE COMMITTEE

Oluf Kiaer, Chairman

EXHIBIT COMMITTEE

FINANCE COMMITTEE

. G. Olsen, Chairman

FESTIVAL PROGRAM

Thomas Bull, Chairman

Anton Wetlesen, Chairma

PUBLICITY AND PUBLICATIONS

Harry Sundby-Hansen, Chairman

GENERAL OFFICERS

Oluf Kiaer, Chairman Thormod Jullum, Secretary A. N. Rygg, Treasures
AMERICANS OF POLISH LINEAGE

Dr. S. Grotowski, Consnl-General, Honorary Chairman

F. X. Jagocki, Chairman

C. Kozlowski, Vice-Chairman

Mrs. B. Zytkiewicz, Vice-Chairman

What

Agnes Andrzewsetar

W. Kaminski, Treasurer

Salik, Recording Secretary

L. Pilarski, Advisory Member

Dr. M. Szawlewsli, Press

Sigismund Stojowski, Music

H Ievwinski-Corwin Publications Chairmat AMERICANS OF PORTUGUESE LINEAGE George Duarte

AMERICANS OF RUMANIAN LINEAGE

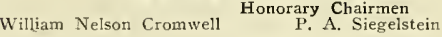

T. Tileston Wells Leon Feraru, Chairman

COMMITTEE ON FINANCE Charles Moran, Cbairnan

COMMITTEE ON FESTIVAL

Louis Diamant

COMMITTEE ON RECEPTION

COMMITTEE ON EXHIBIT

Jean U. Koree, Chairman

D. D. Dimancescu, Acting Chairman Radu Belian, Secretary

$\begin{array}{lll}\text { Henry Clews } & \text { Radu Irimescn } & \text { T. Stefaniu } \\ \text { John Foster Dulles Jean Paleologue } & \text { John Raica }\end{array}$

John Foster Dulles Jean Paleologue John Raica

Arthur Zentler
Arthur Kolnik

Henty Sasch

AMERICANS OF RUSSIAN LINEAGE

Prof. N. P. Makaroff, Chairman

Jos. B. Polonsi Fival PROGRAM , P. Makaroft

Nicholas K. Roerich, Chairman AND DECORATIONS
B. Artzicaskeff W. Virrick N. Skitski AMERICANS OF SCOTTISH LINEAGE EXECUTIVE COMMITTEE William Taylor, Chairman EXHIBITS AND ARTS

lexander Mackintosh J, Massey Rhind FESTIVAL PROGRAM William Taylo

COMMITTEE ON PUBLICATION

Wm. M. MacBean John J. MacPhee Charles C. Stoddard

AMERICANS OF SWISS LINEAGE ORGANIZATION COMMITTEE

O. H. Ammann Edward Escher Alfred Hafner Paul A. Isler Robt. Schwarzenbach Dr. J. Schwarzmann AMERICANS OF SYRIAN LINEAGE Joseph A. Zaloom Dr. E. Mussallem

AMERICANS OF WELSH LINEAGE EXECUTIVE COMMITTEE

Robert D. Williams, Chairman

John Lloyd Thomas, Vice-Chairman and Treasure

T. D. Bowen, Chairman of Finance Committee

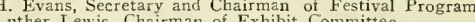
Talli E, Morgan, Musical Director

Mrs. Elizabeth Broadhead William O. Jones George M. Lewi

Rev. Hugb D. Jones E. C. Morris T. D. Bowen U. Lloyd Roberts MUSIC COMMITTEE

Tali Esen Morgan, Director F. C. Morris, Chairman Edward Jones AMERICANS OF SWEDISH LINEAGE

EXECUTIVE AND FINANCE COMMITTEE

Dr. Johannes Hoving, President Dr. Victor O. Freeburg, Vice-President Grastaf Sundelius, Corr. Secretary John H. Johnson, Rec. Secretary

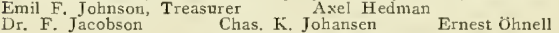

\section{STUDY COMMITTEE}

Dr. Victor O. Freeburg, Chairman Erik W. Wallin, Secretary

Dr. Amandus Johnson, Emil F. Johnson BOOK COMMITTEE Dr. F. Jacobson, Chairman
Dr. Amandus Johnson Ernst Skarstedt Dr. Victor O. Freeburg, Secretary

Chas. K. Johansen, Chaiman PUBICITY COMMITTEE EXHIBITION COMMITTEE EXHIBITION COMMITTEE

Chas, Nickels PROGRAM COMMITTEE

John Olin

John H. Johnson, Chairman Mrs. Helga Hoving Hö Eric Hagström HONORARY AND ADVISORY COMMITTEE

H. Björnström-Steffanson Dr. Adolph Burnett Benson Alex. Olsson

H. Björnström-Steffianson
Hon. Adolph O. Eberhart Karl Von Rydingsvärd

$\begin{array}{lll}\text { John Aspegren } & \text { Charles L. Eckman } & \text { Hon. Samuel Car } \\ \text { J. E. Hillberg } & \text { A. A. Anderson } & \text { John Söderström } \\ \text { Ernst J. Berg } & \text { Richard Hogner, M.D. Olof Ohlson }\end{array}$

Ernst J+ Berg

rank Mossbers

Andrew Tofft

Andrew Tofft

Hon. John Lind

Anton H. Trulson

Nels Hokanson

Ernst W. Olson

Anders Schön

Othelia Myhrman

Dr. Victor Nilsson Prof. A. A. Stomberg

AMERICANS OF UKRANIAN LINEAGE

Basil Lozuta Chairman John Fedun, Vice-Chairman Basi] Lozuta. Chairman 


\section{AMERICANS OF LATVIAN LINEAGE}

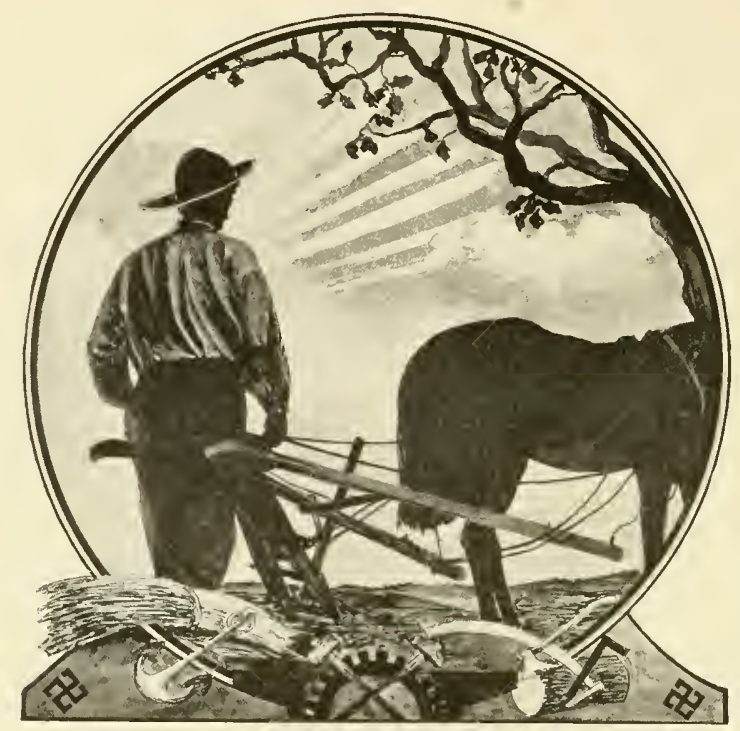

From Latvia the Farmer Follows West to the

Fertile Fields of America

HE Letts come from Latvia, one of the newly-formed Baltic republics. Although in the past Lettish immigrants in America have been classified as Russians, the Letts are an entirely distinct people of Indo-European origin, and the Lettish language has the distinction of being of all living languages the nearest to the ancient Sanskrit from which all Indo-European languages originated.

The principal contribution made by Letts to America is skilled labor and the trades in which the Lettish immigrants are especially proficient are cabinet-making, carpentry, gardening and machine construction; besides that, the Letts have contributed to this country sailors, farmers, and also professionals, such as doctors, engineers, lawyers and musicians. Lettish women are exceptionally skilled needleworkers.

The Letts arriving in this country do not group themselves into colonies, but rather prefer to scatter throughout the country. Thus the Letts assimilate very easily, forming a very pliable material for Americanization. Owing to this fact, the contributions of Letts to America are difficult to estimate. But wherever they go they display their characteristic traits of industriousness, conscientiousness and perseverance.

The festival of song presented by this group consists of a vast chorus from three cities. To the accompaniment of this vocal orchestra are given tableaux, contrasting Lettish agriculture from the days of the wilderness to modern times in Latvia with pictures of the happy farmer in America.

The Lettish Section has chosen for its exhibit a cottage furnished with characteristic furniture and decorated with needlewrork designed and executed by Americans of Lettish lineage. In front of the cabin a little garden is arranged with various plants and flowers. Thus the entire exhibit illustrates, concretely, cabinet-making, carpentry, needlework and gardening. 


\section{AMERICANS OF LITHUANIAN LINEAGE}

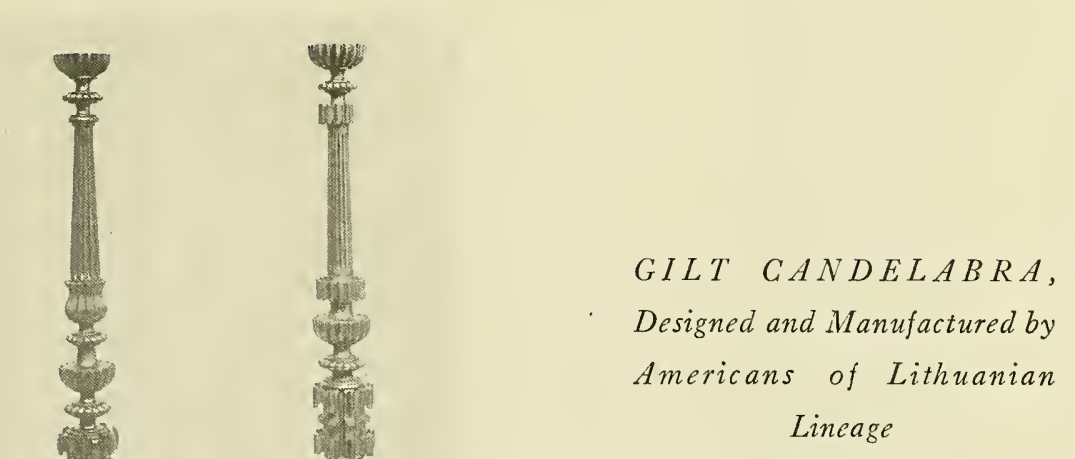

MERICANS of Lithuanian lineage have figured in American life since 1777, when a considerable number of them accompanied Thaddeus Kosciusko, himself of Lithuanian birth, to fight for American independence.

It was not till a century later that many Lithuanians came to America, but after that immigration was continuous. It was directed principally to anthracite districts in Pennsylvania and to industrial centers. A certain number settled in Connecticut. They were impelled to such immigration by depressing economic and political conditions in the home land as well as the desire for freedom.

Lithuanians are now in every state. They contribute not only to the industrial but to the cultural life of the country. Their citizenship is demonstrated by their hearty response during the World War. The report of the United States Immigration Commission calls attention to the interest of Lithuanians in naturalization. It is estimated that there are now nearly one-half million Americans who claim Lithuanian birth. Called "the first Aryans in Europe," a stalwart, blue-eyed people, the Lithuanians are noted for their steady industry by which they have greatly enriched America.

The exhibit of Americans of Lithuanian descent shows the transition of the hand-weaver in the old country to the power looms in this. Workers engaged on both kinds of looms demonstrate the craftsmanship of this interesting group. Their festival of choir and folk singing and tableaux of industrial work is a dramatization of their activities. 


\section{AMERICANS OF NEGRO LINEAGE}

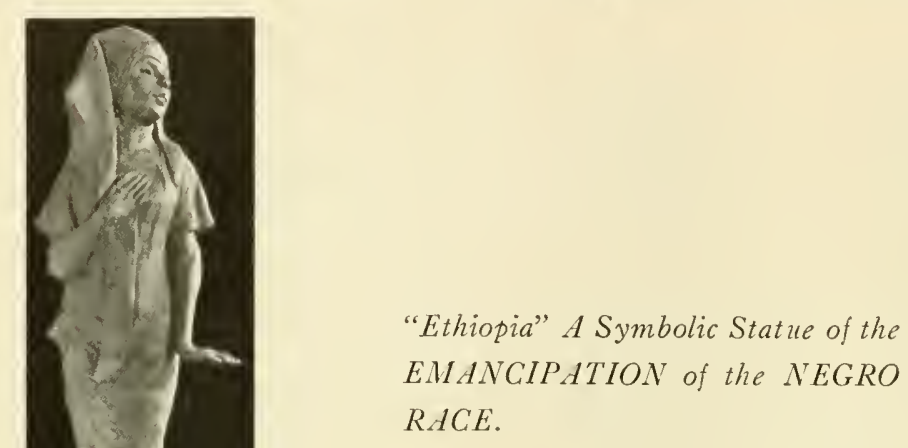

From the Exhibit

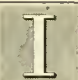

$\mathrm{N}$ the making of America, the part played by the African group is of tremendous importance. His great contributions have been labor, personal service and music.

Negro labor in slavery and freedom, cleared the forests and swamps for the great agricultural regions of the South. It entered America one year before the Puritans and only twelve years after the Cavaliers. From the early 17th Century to the present day, Negro labor has been indispensable in the fundamental industries of the South. On its work depend the great crops of cotton, sugar, tobacco and rice. Negroes are also engaged in the operation of coal mines, fisheries and transportation. It has furnished faithful personal and domestic service and recently has succeeded in the skilled trades.

In 53 years of freedom the Negro has increased his homes owned from 12,000 to 600,000; farms operated from 20,000 to $1,000,000$; business enterprises from 2,100 to 50,000. He has increased in literacy sixty per cent. and the number of his teachers from 600 to 38,000 . The sum spent from his own pocket for his own education has increased from $\$ 0,000$ to $1,700,000$ dollars; his church property from $1,500,000$ dollars to $85,900,000$ dollars, and his general wealth from $20,000,000$ dollars to $1,100,000,000$ dollars.

Churches, colleges and great social agencies have been organized by the Negro. This race has produced orators, writers, and educators. It has given to this country the only distinctively "American" music; the "Sorrow Songs" or Jubilee Music and the syncopated instrumental and vocal rhythms.

The Negro exhibit is designed to symbolize the origin of the race in Africa and its progress in America. WVall decorations will show their industrial contribution to the nation and the educational work among those of their own race. The industrial school will be depicted. Their AIusical festival typifies their wonderful contribution to this branch of art. 


\section{AMERICANS OF NORWEGIAN LINEAGE}

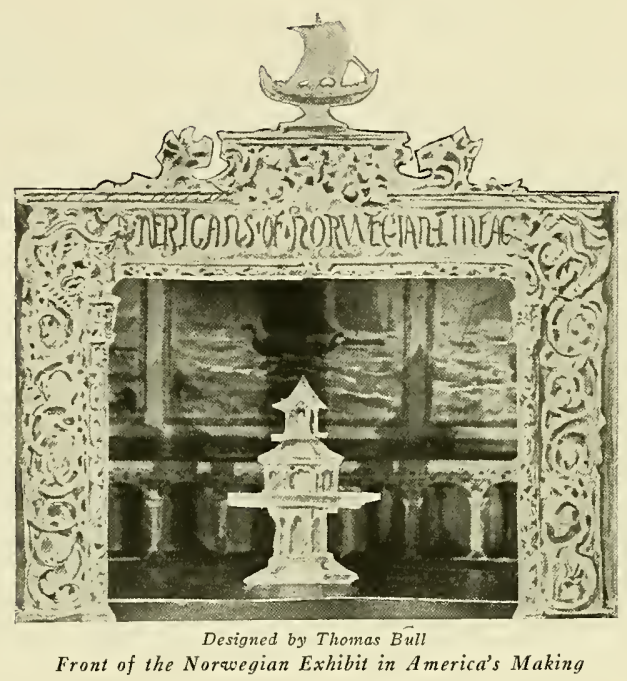

I

ROM the dim days of Norse adventure and discovery to the present, the seafaring activity of the Norwegians has kept them in touch with America. Over a hundred years ago the first large group of Norwegians came to this country. Now there are settled here about half a million Americans born in Norway, while something like four millions of people of all generations trace their lineage to Norway.

Nearly half of the gainfully employed Norwegians are engaged in agriculture and allied food-producing industries. They were pioneers in the Middle West and Northwestern States. They cleared and cultivated this section. The percentage of farm owners and operators among this group is the highest of any ethnic group in America.

As seafarers they have also entered into America's economic life and are represented in large numbers in shipping and marine occupations on the coasts and on the great lakes. Fisheries, as a related industry in which Norwegian descendants excel, claim large numbers of them on the Pacific Coast and in Alaskan waters. In the fish-packing industry Norwegians who are largely represented therein have contributed special methods of packing now generally adopted. Lumbering, the skilled trades and machine shops count many of these Americans among their workers. Those foremost in the professions of engineering, architecture and other technical professions, include these vigorous people.

Sports and music have been contributed to America by immigrants from Norway. Skiing, introduced by them, has become a popular American sport. Singing societies and musical organizations flourish in all centers where people of Norwegian lineage predominate.

The exhibit of Americans of Norwegian lineage depicts their important part in the shipping of this country. A painting shows the arrival of Lief Ericson on these shores. The modern aspect of their seamanship is interpreted by a beautiful mural showing Norwegian sailors along our coasts. A third mural represents farming in the Northwest. Grouped around these central ideas are many relics and historical objects. 


\title{
AMERICANS OF POLISH LINEAGE
}

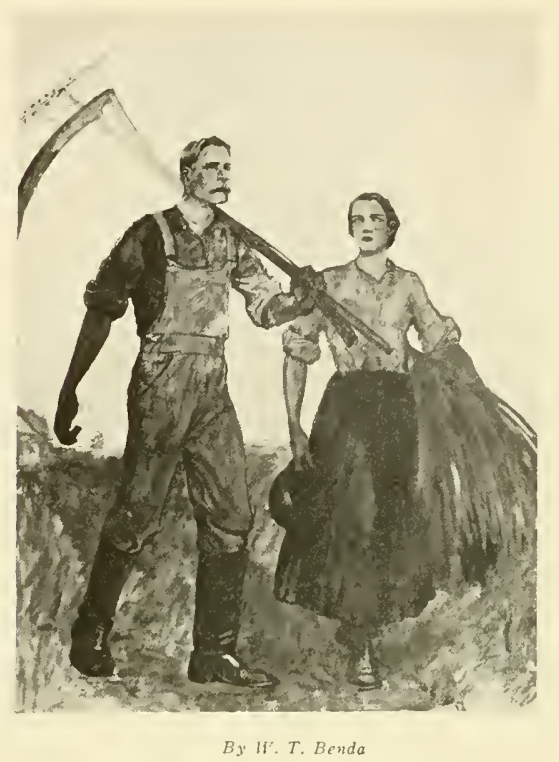

\author{
The I'ision of Harvest \\ Realized in America
}

HE polish immigrant group, although unimportant until the latter half of the nineteenth century, was represented in America in Colonial times. During the War of Independence, these immigrants gave three distinguished leaders to our cause.

The present Polish population of the United States is concentrated chiefly in the great industrial centers, occupied in iron and steel manufacturing, sugar refining, slaughtering and meat packing. By no means confined to industry, however, this group has settled upon the land and frequently engaged in highly specialized forms of farming, such as tobacco culture and truck gardening.

In 1903 there were 810 Polish settlements, chiefly agricultural, in New England and the Middle West. Their service has been to bring considerable tracts of poor and unused land under cultivation.

Americans of Polish lineage have greatly enriched American culture in the realm of music. Many of their musicians have earned a conspicuous place on operatic and concert stage and are numerously represented in our orchestras. In sculpture and painting, Americans of Polish ancestry have done distinguished work.

The exhibit of Americans of Polish lineage consists of three parts. The first, two large decorative panels, represents Polish immigrants engaged in farming and mining in the United States; the second consists of portraits of famous Poles in America; and the third displays concrete evidence of Polish technical skill. 


\section{AMERICANS OF PORTUGUESE LINEAGE}

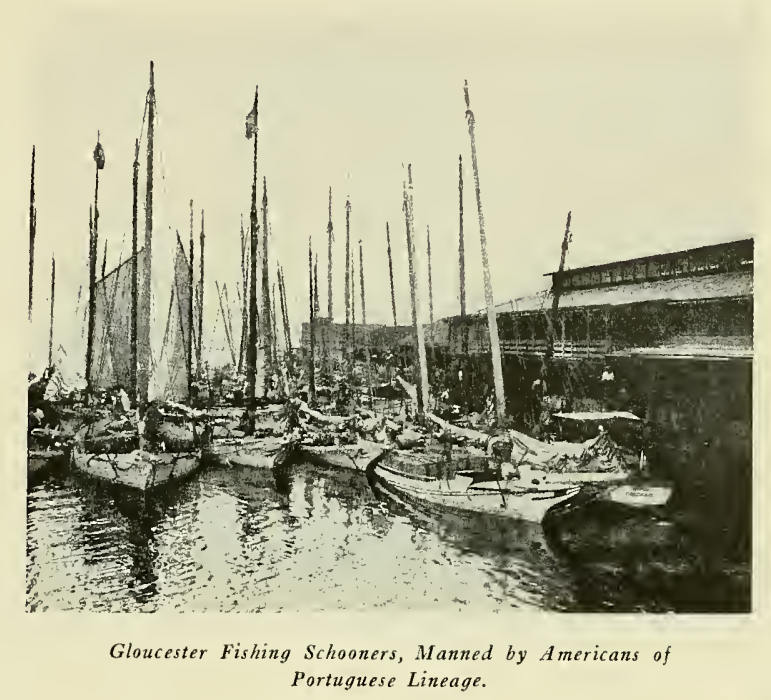

1

HE first connection between the American continent and Portugal was established in the beginning of the 16th Century when Cortereal made an exploring expedition which impressed his nickname "the labrador or farmer". upon the eastern coast of Canada.

Two centuries later a number of Portuguese de sirous of escaping religious persecution settled in Holland and. moved on to New Amsterdam. In one of New York's oldest cemeteries may still be found Portuguese names and inscriptions on a number of tombstones.

In 1820 political refugees from Portugal landed in America and in 1849 a number of them migrated to California and started settlements on the Pacific Coast. The total of Americans of Portuguese descent is estimated at about 300,000. Most of them are located in California where they have done much to develop the agricultural prosperity of that fertile state. In Massachusetts they are occupied as fishermen and as weavers in the cotton mills.

Sturdy citizens of exceptionally high honor are the Americans of Portuguese extraction. They have given distinguished artists and scientists to this country. 


\title{
AMERICANS OF ROUMANIAN LINEAGE
}

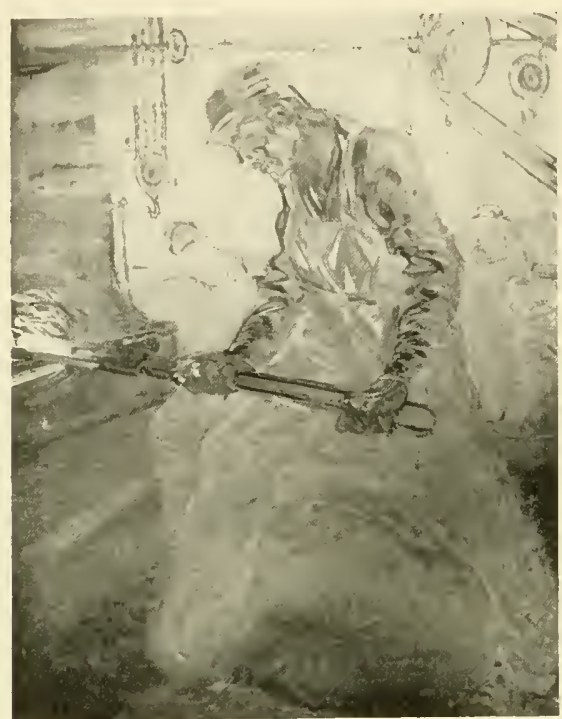

\author{
Panel of Steel Worker \\ From Exhibit \\ A mericansof \\ Roumanian Lineage
}

OUMANIAN immigration is of quite recent date, but the names of certain individuals appear on the page of American history. In the Civil War, Nicholas Dunca and Major George Pomutiu shed their blood in the great struggle. But most of the 150,000 Americans of Roumanian birth are of the first generation.

More than half this number live in New York, Ohio, Pennsylvania, Michigan and Illinois. No part of the United States is without some members of this group. They are found in almost every walk of life. Literature, art, science, education and professions are followed by these citizens from a far country. To music they have contributed Alma Gluck.

The great majority of Roumanian-born Americans have, however, given their brawn to the building of America. Peter Roberts, in "The New Immigration," says: "American industry needed the mercurial Italian and Roumanian. There was much coarse, rough and heavy work to do in mining and construction camps; in tunnel and railroad building; around smelters and furnaces. Nowhere in the world could employers get laborers so well adapted to their need. as the countries of Southeastern Europe."

The spirit of Labor brought to this country by those of Roumanian lineage is a fundamental part of this exhibit. The laborer, farmer and miner is graphically depicted. So is the artistic craftsman in delicate embroideries. The central painting shows the aspirations of the Romanian immigrant toward life in his adopted country, America. 


\section{AMERICANS OF RUSSIAN LINEAGE}

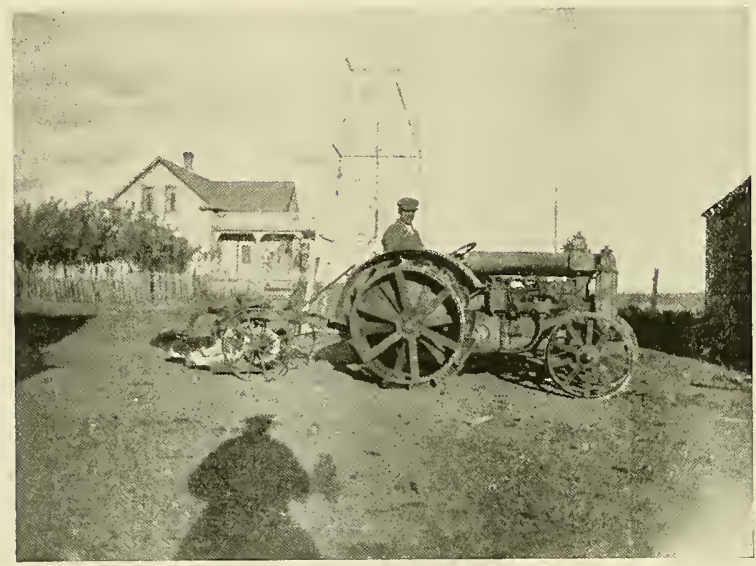

An American of Russian parentage on his farm in the great West using modern agriculture machinery

USSIANS began to emigrate to America early in the nineteenth century, but no great immigration had occurred prior to 1880 . At this time large numbers subjected to religious persecution sought an asylum here. To-day we have more than 3,000,000 Americans of Russian lineage. They are concentrated in the Middle Atlantic States and small groups are spread throughout the country.

The arts and agriculture are the main Russian contributions to America. Many Russians of education and culture brought with them to America a wonderful heritage of musical, literary and artistic achievement. They translated the Russian novels which opened new realms to us; they introduced typical Russian music through individual artists and such organizations as the Russian Symphony Orchestra and the Russian Cathedral Choir. The Russian ballet school is an educational force. Artists and sculptors of Russian lineage have produced noteworthy works of art. Their traditions have profoundly influenced the drama and staging of plays and opera.

In the Southwest and Far West, Russian immigrants have been successful in building up large agricultural communities. Their product has largely been wheat, flax and other seeds and plants native to Russia. These people have engaged in such basic industries as mining, iron and steel manufacture, and lumbering. Their arts and crafts, which include brass and copper work and beautiful embroideries, have been brought into the United States and widely popularized.

The exhibit of Americans of Russian descent shows the chief contributions of this group to our nation. A huge map of the United States shows Russian immigrant settlements. Seed and plant exhibits demonstrate their agricultural work. The art of the Russian ballet and of stage decoration is beautifully illustrated. Russian furs, Russian arts and crafts, the Russian samovar, are evidences of the concrete commercial gifts brought by this group to America. 


\section{AMERICANS OF SCOTTISH LINEAGE}

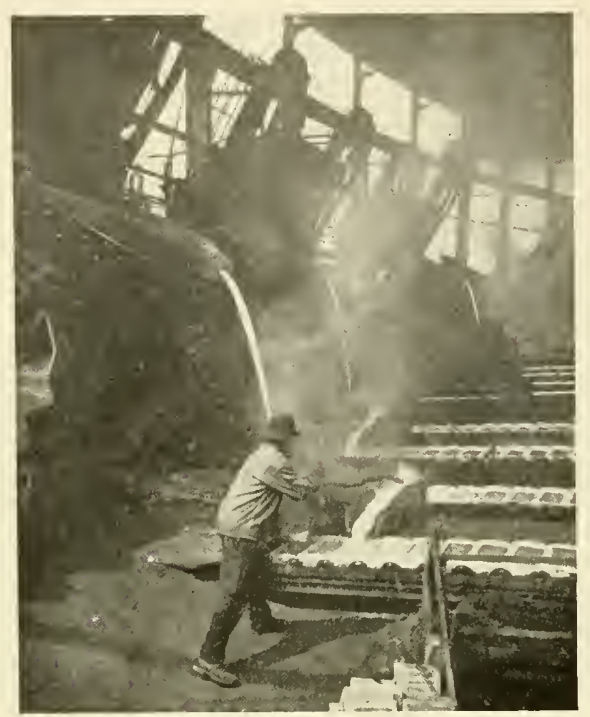

The Heritage of Scotch

Diligence has Helped to

Build Our Stcel Industry

Copyrighted by Underwood and Underitood, N. Y.

COTSMEN have left their mark on every period of American history from earliest Colonial times to the present day. A number of Highlanders who settled on the border did yeoman service in clearing and holding the frontier. From Scotland came the material for some of the most important statesmen, naval and military leaders of Revolutionary times.

Americans of Scotch descent have proved of incalculable value to the development of the commerce and industry of this nation. They built up many of our chief mercantile establishments, banks, the manufacture of iron and steel, railway transportation and the management of the ship building industry. Their inventions-typified by the manufacture of illuminating gas--have been tremendous economic assets.

Education in America has been deeply influenced by our citizens of Scotch descent. Bringing both reverence for learning and university training, early immigrants contributed many teachers to America, founded several universities and exerted a leading influence on the system of instruction.

The Scotch have given to the American people many of its favorite songs and ballads. Their national literature of story and poetry has had a powerful cultural influence in this country. Golf, which has now become one of America's most popular games, was introduced from Scotland.

The exhibit of Americans of Scottish lineage bas worked into its decorative scheme the story of their contributions to America, chief of which are their high ideals, their love of liberty, their loyalty. "A man's a man for a' that" is lettered across the back of the exhibit. Panels graphically picture the historical and industrial representations of the Scotch part in America's Making, with names of their great citizens blazoned high. This group presents a festival program of the songs and ballads which have become the home songs of America, offset by the Highland bag-pipers and characteristic dances. 


\section{AMERICANS OF SWEDISH LINEAGE}

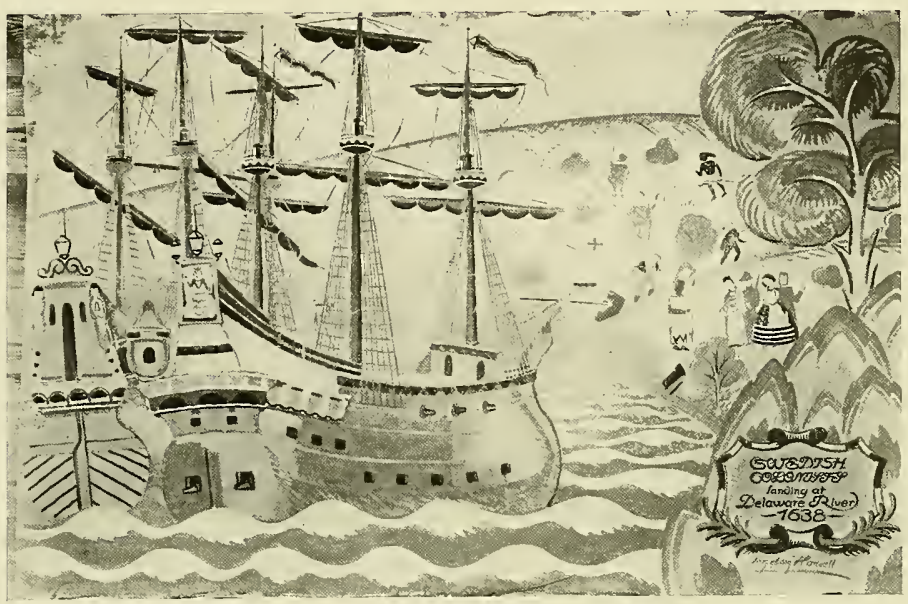

One of the Murals from the Exhibit symbolizing Early Explorations

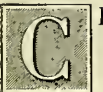

ITIZENS of Swedish lineage have contributed in great share to the material growth and progress of America and have made valuable additions to its spiritual and cultural life.

For two hundred and eighty-three years they have formed an integral and important part of what finally became the American nation. They have been prominent in its political life during the Colonial period and always have fostered respect for law and order and exerted a wholesome influence for good government.

Their records as soldiers, sailors and officers is surpassed by none. Some of our leading educators and scholars, and many of our foremost scientists and inventors are of Swedish origin.

The music of our land has been greatly enriched by these people, who helped greatly to improve general musical taste. They have advanced sculpture and painting, made many contributions to the industrial arts, and influenced our architecture.

Swedish descendants have cleared and cultivated over 12,000,000 acres of land, and they have established 2,000 churches and a large number of schools, charitable institutions and beneficial and social welfare societies. They have published hundreds of newspapers and thousands of books, and, like their ancestors in Sweden, spend more on education per capita than descendants of any other nationality.

They have introduced new ideas into certain branches of our school curricula, especially an emphasis on manual training. Gymnastics in the American Army and in many of our schools are founded on Swedish theories and have been ably taught by a large number of instructors of Swedish extraction. Mechanotherapy, which has grown to such importance, was introduced into this country under Swedish inspiration and has been largely fostered by men and women of Swedish extraction.

In the exhibit of Americans of Swedish lineage three lines of activities are emphasized: Swedish settlements in Delaware, the defense of this country and modern farming methods in the Northwest. These three ideas are illustrated by large murals, on each wall surrounded by painted portraits of important and famous Americans of Swedish lineage. The festival of this group includes gymnastics, singing by united societies and folk dancing. 


\section{AMERICANS OF SIVISS LINEAGE}

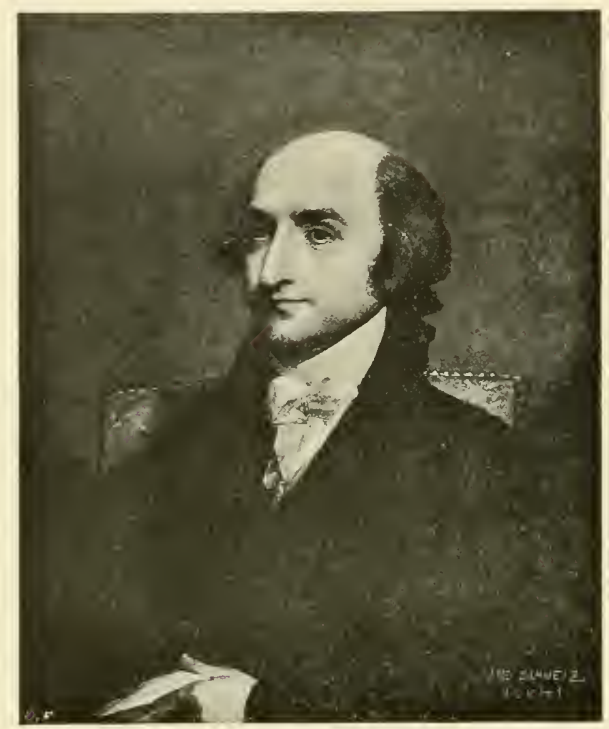

Stuart's Portrait of ALBERT GALLATIN Swiss-born American Secreiary of U.S. Treasury $I S O I-I \mathcal{I} 3$

WISS immigration to America has been steady and individual rather than concentrated in time or mass. In the early history of the United States, Americans born in Switzerland have prominently figured.

For years Americans of Swiss lineage imported into the country articles manufactured in Switzerland, such as embroideries, silks, watches, cheese and chemical products. For some time now they have been engaged in these industries in America in which they have introduced skilled workmen born in Switzerland, and to which they brought experience and organized knowledge.

Dairying has been widely developed by these Americans in the Middle West, the mountainous meadows of the far West and on the Pacific Coast. Their success was due to the thorough knowledge of grazing and dairying which they brought with them. Coming from a country of tourists, these citizens knew how to build up some of our finest hotels and restaurants. Trained experts in banking from Switzerland are found in many banking institutions and often in commanding positions.

Education has felt the influence of the teachers who have made their homes here. Public schools have adopted physical training partly as a result of their efforts in combination with the Germans through their "Turnverein." With Germans and Swedes they have developed, through their singing societies, American interest in music and song. To America the Swiss brought their principles of Liberty, Justice and Self-government, which in private life they demonstrate by a high standard of fair dealing and sensitive honor. 


\section{AMERICANS OF SYRIAN LINEAGE}

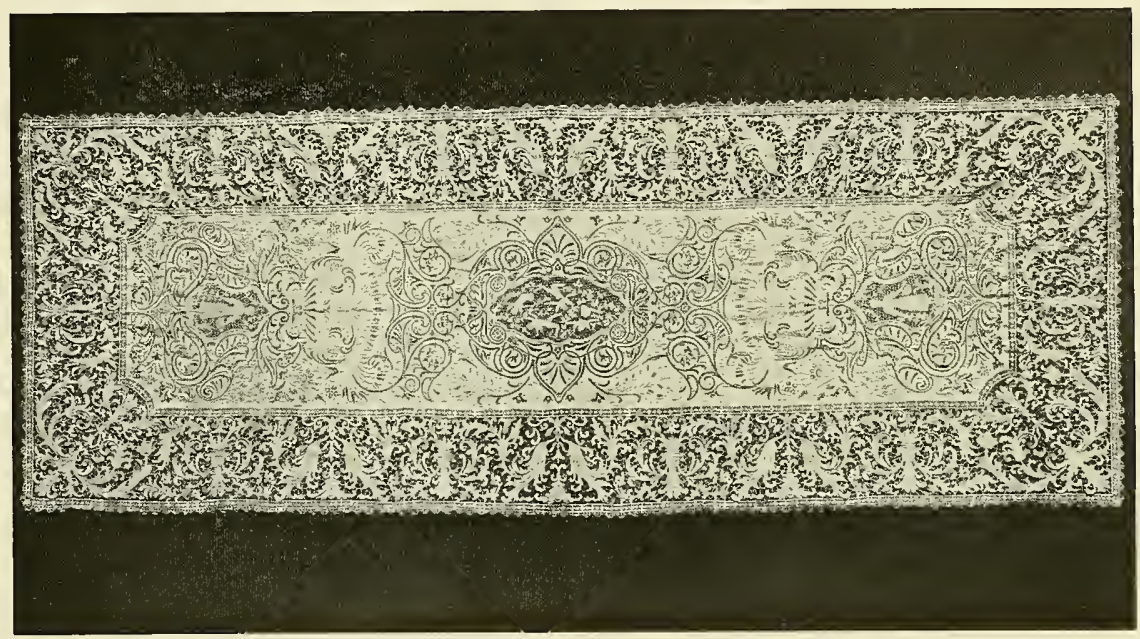

A Characteristic Importation of Lace

7 HE Syrian immigration to America has taken place for the most part since 1885 . There are at present about 200,000 Syrians throughout this country, many of whom have become citizens of the United States.

The Syrian's most pronounced racial trait is his commercial proclivity-a characteristic which he inherits from the ancient Phoenicians. He exports American merchandise to his kinsmen all over the world, and his extensive importations have done much to promote the popularity in the United States of finer articles of hand-made laces and embroideries distinctive of Old-World art. He has developed the manufacture of kimonos to such an extent that it now gives employment to thousands of workers.

The Syrian is also doing his part in the making of America by his deep-rooted love for law and order and his tireless industry.

The exhibit of Americans of Syrian lineage includes both hand work and the special importations which are their significant contribution as merchants. This interesting display consists of rugs, brass hand-work, mother-of-pearl work, kimonos, which Syrians manufacture on a large scale, pistachio nuts and beautiful linens and laces. 


\section{AMERICANS OF UKRAINIAN LINEAGE}

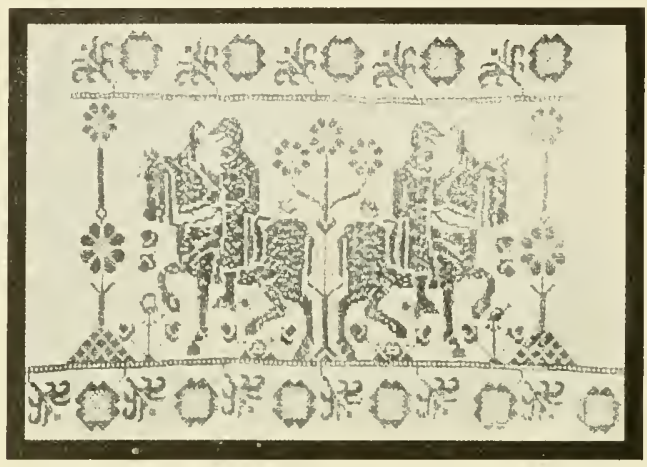

A typical pattern of Ukrainian embroidery

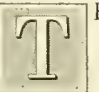

HERE are approximately 1,000,000 people of Lkrainian lineage in the East and Middle WVest sections of the Lnited States. Pennsylvania has almost 100,000 of this number, who have settled near Pittsburgh. Large colonies have also settled in Yew York, New Jersey, Ohio, Illinois and Michigan, while smaller settlements are in North Dakota, Minnesota and California and Oregon.

Immigration from the Lkraine began about 1870, but was important before 1900. Gradually the influx increased, until just before the war we received about 100,000 Ckrainians annually. The gifts of this group have been important rather than conspictous. Probahly the greatest L krainian contributions have been in the coal mines and iron and steel industries of Pennsylvania, where by their courage, endurance and brawn they have noticeably increased our annual output.

Ukrainians are well represented in almost every factory in America's large industrial regions, and are especially active in the textile industry of New Jersey. The skill of their artisans is noteworthy, especially in wood-working, embroideries, tailoring, weaving, work in furs and beads, and clock-making. This group has already entered into farming, and has a fair representation of small tradesmen. They are fast becoming a very real factor in American life and its art. Their deep interest in music is a potential contribution.

The exhibit of Americans of Ukrainian lineage emphasizes its beautiful embroidery produced on the spot by women working by hand and loom. Samples of radium ore form part of an exhibit of mining. Wood working and wood inlays and bead work will he demonstrated by actual workers. 


\section{AMERICANS OF WELSH LINEAGE}

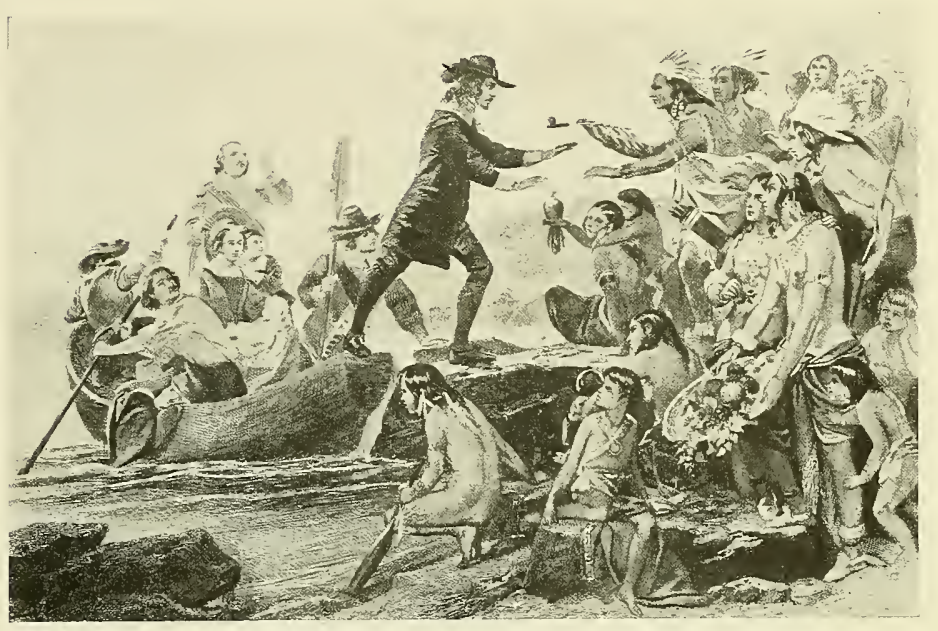

Roger Williams Accepting the Pipe of Peace.

Colonial days many younger sons of Welsh families settled in the South from whom are descended many of our best known southern families. Many other Welshmien among Pilgrims and Pioneers helped colonize New England.

Roger Williams founded Providence, Rhode Island, and William Penn in Pennsylvania with other Welsh Quakers made the most important large settlements. Americans of Welsh lineage contributed many soldiers to the cause of Independence and such patriots as Robert Morris and Patrick Henry. Welsh names and Welsh blood are found among many of our most distinguished statesmen.

Several of our colleges were founded by the Welsh people, including Harvard, Brown and Williams. To our industry they contributed the invention of high-pressure engines, established the first woolen mill, helped to found the iron and steel industry and did much to promote agriculture and mining.

They introduced into America the great Welsh musical and literary festival called the Eisteddfod. By their love of song and the organization of their great choir, they have been a musical inspiration to many communities.

The exhibit of this section shows the early historical background of the Welsh in this country. The settlement of Pennsylvania by Penn and the pioneering of Roger Williams are shown. The great industrial contribution of early mining is graphically depicted by large blocks of tin, iron, slate and coal. The Welsh influence in education is illustrated by the part they played in the founding of Yale and Princeton. 


\section{GUILD OF THE NEEDLE AND BOBBIN CRAFTS}

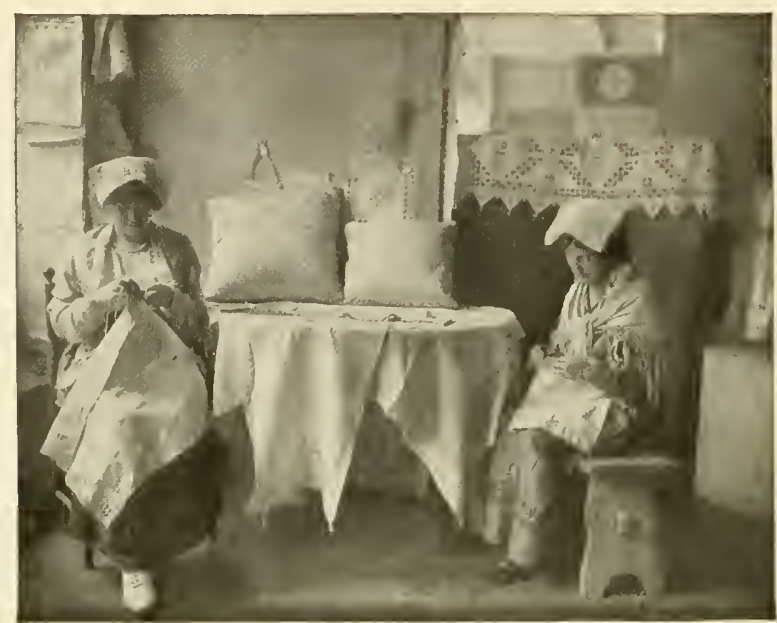

Women of Italian descent on cut-linen at the Scuola d'Industrie Italiane

HE Guild of the Needle and Bobbin Crafts, working in cooperation with the Needle and Bobbin Club and the People's Institute is an association formed to stimulate and maintain interest in the hand-made fabrics of foreign and native groups; to assist in preserving the racial character of the fabrics in so far as they are worthy in design and workmanship, and to assist in the production and marketing of the same. They hold and take part in exhibitions and have established a clearing-house for the information and education of the public regarding the art standards of textile handiwork and for the federation of various industries.

In every land needlework has for centuries been the medium of expression of the woman in the home. In their desire to become Americanized, the foreign women are apt to discard those things which are of most value to their new country and themselves and substitute for them the expression of art, so called, which bears the stamp of the new country.

Allen T. Burns writes, "Foreign women have been the least in touch with American life, and less has been done to unite them solidly with the native-born. To the extent that their needlecraft can be made to meet demands of America for textile art, you will not only tie these women to our country, bit add a decidedly necessary element to our national life."

The exhibit of this guild will set forth counterpanes from Colonial New England and gowns gay with Ukrainian designs. Textiles and needlework showing the distinctive patterns and technical methods introduced by workers from all the various races into America will be displayed. At a glance the source of inspiration can be seen because each piece is marked and its history given. 

SMITHSONIAN INSTITUTION LIBRARIES

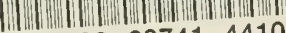

$3908800741 \quad 4410$

520 2025I

1981150

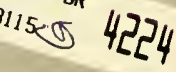

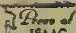

ISTic 



$$
\text { ig. }
$$

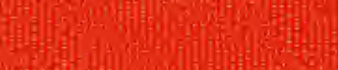

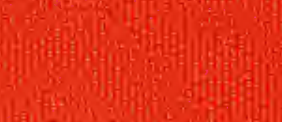

(10)

4.

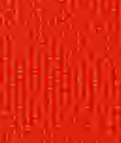

ivising<smiles>C1=C[GeH]=C1</smiles> 